\title{
Natural products inhibitors of the angiotensin converting enzyme (ACE). A review between 1980 - 2000
}

\author{
José M. Barbosa-Filho*, Valeska K.M. Martins, Luiza A. Rabelo, Marcelo D. Moura, Marcelo \\ S. Silva, Emidio V.L. Cunha, Maria F.V. Souza, Reinaldo N. Almeida, Isac A. Medeiros* \\ Laboratório de Tecnologia Farmacêutica "Prof. Delby Fernandes de Medeiros", Universidade Federal da Paraiba, \\ Caixa Postal 5009, 58051-970, João Pessoa, PB, Brazil
}

\begin{abstract}
RESUMO: "Produtos naturais inibidores da enzima conversora de angiotensina (ECA). Uma revisão entre 1980 - 2000". A inibição da Enzima Conversora da Angiotensina (ECA) é um alvo terapêutico moderno e eficaz no tratamento da hipertensão arterial. Na cascata enzimática que envolve o sistema renina-angiotensina, a ECA promove a remoção dos aminoácidos histidilleucina da angiotensina I para formar o octapeptídio angiotensina II, a qual é fisiologicamente ativa em diversos sistemas, e considerado como um dos mais potentes vasoconstrictores endógenos conhecido. Portanto, uma racionalidade no tratamento da hipertensão seria administrar drogas ou compostos de origem natural que inibam seletivamente a ECA. O presente estudo constitui uma revisão da literatura sobre plantas e moléculas de origem natural com potencial anti-hipertensivo, baseado na inibição in vitro da ECA. A revisão referencia 321 plantas, partes usadas, tipo de extrato e se é ativo ou não. Inclui ainda o nome de 158 compostos isolados de plantas superiores, esponjas e algas marinhas, fungos e venenos de cobra. Alguns aspectos de pesquisa recente com produtos naturais direcionados à produção de drogas anti-hipertensivas também são discutidos. Nesta revisão 148 referências foram consultadas.
\end{abstract}

Unitermos: Enzima conversora da angiotensina, efeito anti hipertensivo, agentes hipotensivos.

\begin{abstract}
Inhibition of Angiotensin Converting Enzyme (ACE) is a modern therapeutic target in the treatment of hypertension. Within the enzyme cascade of the renin-angiotensin system, ACE removes histidyl-leucine from angiotensin I to form the physiologically active octapeptide angiotensin II, one of the most potent known vasoconstrictors. Therefore, a rationale for treating hypertension would be to administer drugs or natural compounds which selectively inhibit ACE. The present work constitutes a review of the literature of plants and chemically defined molecules from natural sources with in vitro anti-hypertensive potential based on the inhibition of ACE. The review refers to 321 plants, the parts utilized, type of extract and whether they are active or not. It includes also the names of 158 compounds isolated from higher plants, marine sponges and algae, fungi and snake venom. Some aspects of recent research with natural products directed to produce anti-hypertensive drugs are discussed. In this review, 148 references were cited.
\end{abstract}

Keywords: Angiotensin converting enzyme, anti-hypertensive effect, hipotensive agents.

\section{INTRODUCTION}

The Sixth Report of the Joint National Committee on Prevention, Detection, Evaluation, and Treatment of High Blood Pressure defines hypertension as systolic blood pressure (SBP) of $140 \mathrm{~mm} \mathrm{Hg}$ or greater, diastolic blood pressure (DBP) of $90 \mathrm{~mm} \mathrm{Hg}$ or greater, or taking anti-hypertensive medication. The objective of identifying and treating high blood pressure is to reduce the risk of cardiovascular disease and associated morbidity and mortality. To that end, it is useful to provide a classification of adult blood pressure for the purpose of identifying high-risk individuals and to provide guidelines for treatment. The positive relationship between SBP and DBP and cardiovascular risk has long been recognized.
This relationship is strong, continuous, graded, consistent, independent, predictive, and etiologically significant for those with and without coronary heart disease (Stamler, 1991, Flack et al., 1995). Therefore, although classification of adult blood pressure is somewhat arbitrary, it is useful to clinicians who must make treatment decisions based on a verification of factors including the actual level of blood pressure. Hypertension detection begins with proper blood pressure measurements. Repeated blood pressure measurements will determine whether initial elevations persist and require prompt attention or have returned to normal. According to the National Heart, Lung and Blood Institute (1997), heart disease and stroke remain the first and third leading causes of death, respectively, in the United States and impose an enormous financial and 
social burden on Americans. In particular, the continued high prevalence of hypertension and hypertension-related complications of stroke, heart failure, and end-stage renal disease in the southeastern United States makes these diseases a public health concern for all who reside in this region, particularly African Americans (Hall et al., 1997). Approximately 50 million adult Americans have hypertension and are still unaware that they have high blood pressure (Burt et al., 1995). In addition, most persons with hypertension have additional risk factors for cardiovascular disease (Furster; Pearson, 1996). Thus, prevention and treatment of hypertension and target organ disease remain important public health challenges that must be addressed as we enter the new millennium.

There are different way to treat the problem related to arterial hypertension. Treatment leading to lower levels may be useful, particularly to prevent stroke (Du et al., 1997), to preserve renal function (Lazarus et al., 1997) and to prevent or slow heart failure progression (Krumholz et al., 1997, Neaton et al., 1993). The goal may be achieved by lifestyle modification, alone or with pharmacological treatment.

\section{Non-Pharmacological treatment of arterial hypertension}

The main objective of hypertensive treatment is to reduce the high morbidity and mortality. As well as reducing the pressure, an important objective of treatment is to control other cardiovascular risk factors. Lifestyle modifications offer the potential for preventing hypertension, have been shown to be effective in lowering blood pressure, and can reduce other cardiovascular risk factors at little cost and with minimal risk (Appel et al., 1997). Even when lifestyle modifications alone are not adequate in controlling hypertension, they may reduce the number and dosage of anti-hypertensive medications needed to manage the condition (Neaton et al., 1993, Singer et al., 1995).

\section{Pharmacological treatment of arterial hypertension}

progression to more severe hypertension, and all-cause mortality (Psaty et al., 1997, Moser; Hebert, 1996).

Actually, there are a lot of alternatives available to treat arterial hypertension, both in schemes of monotherapy and/or combined therapy. The efficacy, security and effects of the different drugs are fundamental criteria to be considered in choosing the antihypertensive treatment scheme for each patient. In Table 1 the conventional pharmacological anti-hypertensive medications are presented, further details see references.

\section{Mechanism of anti-hypertensive effect based on the inhibition of the angiotensin converting enzyme (ACE)}

The renin-angiotensin-aldosterone system plays a pivotal role in the maintenance of vascular tone vis $\grave{a}$ vis peripheral resistance. Renin produced from the juxtaglomerular apparatus of the kindney, splits angiotensinogen to produce the inactive decapeptide angiotensin I. The latter is then converted to the powerful octapeptide vasoconstrictor, angiotensin II by the action of angiotensin converting enzyme (ACE). Angiotensin II also stimulates the synthesis and release of aldosterone from the adrenal cortex, which increases blood pressure by promoting sodium retention (and thereby water retention) in the distal tubules (Ahnfelt-Ronne, 1991). Research suggests that angiotensin II stimulates the production of superoxide anion and hydrogen peroxide in the polymorphonuclear leucocytes, which inactivates the vasodilatory compounds endothelial derived vascular relaxing factor (nitric oxide - NO) and prostacyclin $\left(\mathrm{PGI}_{2}\right.$ ) (Kumar; Das, 1993). ACE also inactivates the vasodilating nonapeptide bradykinin, which theoretically contributes to the hypertensive effects of ACE activity (Ahnfelt-Ronne, 1991) (Figure 1).

Therefore, a good rationale for treating hypertension would be to administer drugs or natural compounds which selectively inhibit ACE. Such selective inhibitors would be capable of decreasing blood pressure and producing natriuresis and diuresis.

Main lifestyle modifications for hypertension prevention and management.

\begin{tabular}{l}
\hline \multicolumn{1}{c}{ Main Lifestyle Modifications } \\
\hline - Lose weight if overweight. \\
- Limit alcohol intake \\
- Increase aerobic physical activity \\
- Reduce sodium intake to no more than $100 \mathrm{mmol}$ per day \\
- Maintain adequate intake of dietary calcium and magnesium for general health \\
- Stop smoking \\
- Reduce intake of dietary saturated fat and cholesterol for overall cardiovascular health.
\end{tabular}

Reducing blood pressure with drugs clearly decreases cardiovascular morbidity and mortality. Protection has been demonstrated for stroke, coronary events, heart failure, progression of renal disease,
In a previous paper this research group has reviewed crude plant extracts and chemically defined molecules with potential antitumor activity for mammary (Moura et al., 2001), cervical (Moura et al., 2002) and 
Table 1. Conventional anti-hypertensive medication

\begin{tabular}{ll}
\hline \multicolumn{1}{c}{ Drugs } & \multicolumn{1}{c}{ References } \\
\hline Diuretics & Kaplan, 1996 \\
Beta-blockers & Heintzen; Strauer, 1994 \\
Alpha $_{1}$-blockers & Grimm, 1989; Lasagna, 2000 \\
Alpha $_{2}$-adrenoceptor agonists & Wallin; Frisk-Holmberg, 1981 \\
Calcium channel-blockers & Wenzel et al., 2000; Zannad, 2000 \\
Angiotensin II receptor antagonists & Burnier; Maillard, 2001; Chung, 1999 \\
Inhibitors of the angiotensin converting enzyme (ACE) & Waeber, 1998; Gustafsson et al., 1998
\end{tabular}

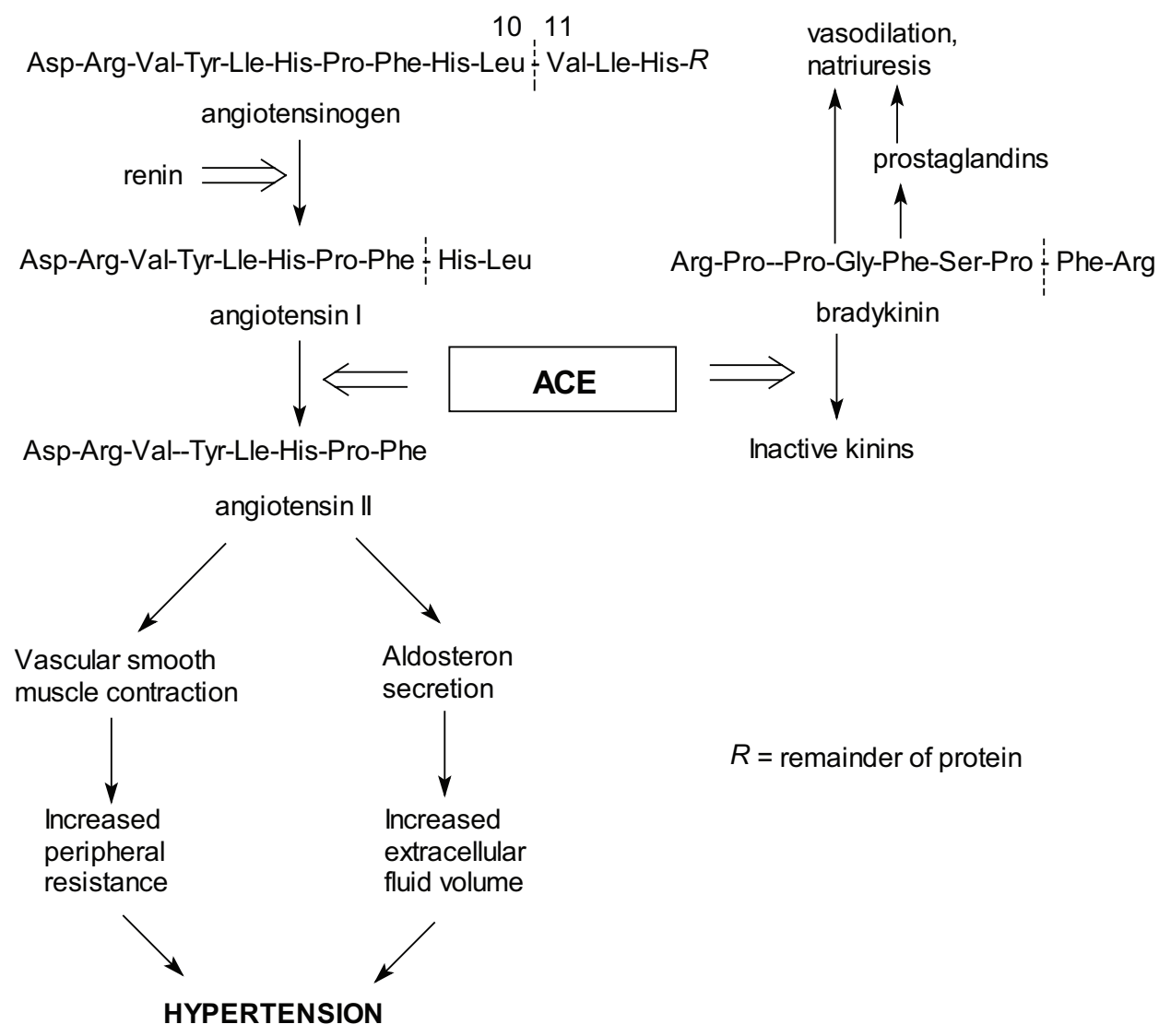

Figure 1. The suggested hypertensive mechanism of angiotensin. Adapted from Hansen et al., 1995 and Hansen et al., 1996a.

ovarian neoplasias (Silva et al., 2003), as inhibitors of HMG CoA reductase (Gonçalves et al., 2000), central analgesic activity (Almeida et al., 2001), employed in prevention of osteoporosis (Pereira et al., 2002), for the treatment of Parkinson's disease (Morais, 2003), with antileishmanial (Rocha et al., 2005), hypoglycemic (Barbosa-Filho et al., 2005), antiinflammatory activity (Falcão et al., 2005, Barbosa-Filho et al., 2006a) and inhibitors of the enzyme acetylcholinesterase (BarbosaFilho et al., 2006b).

In this work we present such natural products, in other words, plant extracts, semi purified fractions, chemically defined molecules isolated from plants and metabolites from fungi that act specifically inhibiting the angiotensin converting enzyme (ACE), which is one of the most powerful known vasoconstrictors.

\section{MATERIAL AND METHODS}

The keyword for this revision was ACE (Angiotensin Converting Enzyme). We made a data search in the Chemical Abstracts, Biological Abstracts and the NAPRALERT (trademark, NAtural PRoducts ALERT) database at the Illinois University, Chicago. The specialized magazines referenced were than searched. 
Table 2. Percentage inhibition of angiotensin converting enzyme (ACE) activity by Euphorbia hirta extracts at doses of $500 \mu \mathrm{g}$ and $150 \mu \mathrm{g}$

\begin{tabular}{lc}
\hline \multicolumn{1}{c}{ Extract and dose } & Mean percentage inhibition of ACE \\
\hline Crude methanol & \\
$150 \mu \mathrm{g}$ & $55.4 \pm 0.02$ \\
$500 \mu \mathrm{g}$ & $90.3 \pm 0.50$ \\
\hline Fraction at $150 \mu \mathrm{g}$ & $18.2 \pm 2.5$ \\
Petroleum ether (non-polar compounds) & $43.7 \pm 4.5$ \\
Chloroform (medium polar) & $48.6 \pm 0.9$ \\
Methanol (polar) & $45.4 \pm 1.8$ \\
Water (very polar) & \\
\hline
\end{tabular}

\section{RESULTS AND DISCUSSION}

Plants which inhibit the angiotensin converting enzyme

Screening for anti-hypertensive effects in traditional medicines has been performed over many years and several animal models have been used (Villar et al., 1986). In western medicine, drug development has become increasingly more mechanistic in focus with the aim of excluding unwanted side-effects. The rationale behind this approach is to identify a molecular target (receptor or enzyme) which has an essential role in the regulation of the disease and then search for ligands, substrates or inhibitors of the target.

In the treatment of hypertension, inhibition of the angiotensin converting enzyme (ACE) is established as a modern therapeutic principle.

Elbl and Wagner (1991) introduced an in vitro assay for the detection of ACE inhibitors in plant extracts. This method is based on the ACE-catalyzed cleavage of the chromophore-fluorophore labelled substrate, dansyltriglycine, into dansylglycine, which is quantitatively measured by HPLC (high performance liquid chromatography). By using this technique, a number of plant species have been found to be active (Elbl; Wagner, 1991).

Williams et al. (1997) using another bioassay, but also involving ACE inhibition, verified that the leaves and stems of Euphorbia hirta inhibited the activity of angiotensin converting enzyme by $90 \%$ and $50 \%$ at $500 \mu \mathrm{g}$ and $150 \mu \mathrm{g}$ respectively using enzyme linked immunosorbent assay (ELISA). The data are presented in Table 2. The study also revealed that the most active ACE inhibitory compounds were present in the polar and very polar fractions of the medium.

The results of the literature survey are presented in Table 3, which lists the effects on angiotensin converting enzyme of 321 plant extracts. The plants are arranged in alphabetical order. Each entry gives the following information in sequence: botanical name, family, part used, type of extract or fraction, whether active or not and reference.
From these studies, is appears to be the possibe, using biomonitored phytochemical methods, to find out new substances potentially active, which may prove important for the development of new substances inhibitors of the angiotensin converting enzyme.

\section{Chemically defined molecules inhibitors of the angiotensin converting enzymes}

Synthetic drugs such as captopril (Ondetti et al., 1977) or teprotide (Ferreira, 1965), a nonapeptide isolated from the venom of Bothrops jararacussu with established ACE inhibiting activity are used as first line drugs in both secondary and primary hypertension. The rising cost of these and other imported anti-hypertensive drugs stimulates the evaluation of new products as a source of cheaper agents. Several classes of ACE inhibitory compounds were isolated from plants, for example, flavonoids (Wagner et al., 1991; Wagner; Elbl, 1992; Hansen et al., 1996b), xanthones (Chen et al., 1992), secoiridoids (Hansen et al., 1996a). For a comprehensive review of these compounds, see Hansen (1995).

The results of the literature are presented in Table 4, which lists the effects on angiotensin converting enzyme of 158 chemically defined molecules. The compounds are arranged in alphabetical order. Each entry gives the following information in sequence: chemical name, class, whether active or not and reference.

\section{CONCLUSION}

This revision focussed initially on the search for information about natural product inhibitors of the angiotensin converting enzyme (ACE). From the literature searched, 321 species of plants and 158 natural substances which inhibit ACE were identifed. These natural products may become important for human clinical treatments.

\section{ACKNOWLEDGEMENTS}

The authors express their sincere thanks to the College of Pharmacy, The University of Illinois at Chicago, Chicago, Illinois 60612-7231, U.S.A., for

Rev. Bras. Farmacogn. Braz J. Pharmacogn 16(3):jul/set. 2006 
helping with the computer aided NAPRALERT search of angiotensin-converting enzyme and CNPq/CAPES Brazil for financial support.

\section{REFERENCES}

Ahnfelt-Ronne I 1991. Enzyme inhibitors as drugs. In: Krogsgaard-Larsen $\mathrm{P}$ and Bundgaard $\mathrm{H}$ (Eds.) A textbook of drug design and development. Switzerland: Harvood Academic Publishers, 302307.

Almeida RN, Navarro DS, Barbosa-Filho JM 2001. Plants with central analgesic activity Phytomedicine 8: 310322.

Ando T, Okada S, Uchida I, Hemmi K, Nishikawa M, Tsurumi Y, Fujie A, Yoshida K, Okuhara M 1987. A novel angiotensin converting enzyme inhibitor produced by a fungus, Doratomyces putredinis. J Antibiot 40: 468-475.

Aoyagi T, Wada T, Kojima F, Nagai M, Harada S, Hachisu M, Murata S, Umezawa H 1986. Inhibitors of aminopeptidase B. Suppress the development of hypertension in spontaneously hypertensive rats. Chem Pharz Bull 34: 4852-4854.

Appel LJ, Moore TJ, Obarzanek E 1997. For the DASH Collaborative Research Group. A clinical trial of the effects of dietary patterns on blood pressure. $N E n g l$ J Med 336: 1117-1124.

Arisawa M, Nimura M, Ikeda A, Hayashi T, Morita N, Momose Y, Takeda R, Nakanishi S 1986. Biologically active macrocyclic diterpenoids from chinese drug "Fang Feng Cao" I. Isolation and structure. Planta Med 52: 38-41.

Arisawa M, Morinaga Y, Nishi Y, Ueno H, Suzuki S, Hayashi T, Shimizu M, Yoshizaki M, Morita N, Berganza LH 1989). Chemical and pharmaceutical studies on medicinal plants in Paraguay constitueints of angiotensin converting enzyme inhibitory fraction from cocu, Allophylus edulis Radlk. Shoyakugaku Zasshi 43: 78-90.

Ball D, Elliott ME, Hadjokas N, Goodfriend TL, Green MJ 1986. Veratridine, angiotensin receptors and aldosteronogensis in bovine adrenal glomerulosa cells. Clin Exp Hypertens 8: 323-345.

Barbosa-Filho JM, Vasconcelos THC, Alencar AA, Batista LM, Oliveira RAG, Guedes DN, Falcão HS, Moura MD, Diniz MFFM, Modesto-Filho J 2005. Plants and their active constituents from South, Central, and North America with hypoglycemic activity. Rev Bras Farmacogn 15: 392-413.

Barbosa-Filho JM, Piuvezam MR, Moura MD, Silva MS, Lima KVB, Cunha EVL, Fechine IM, Takemura OS 2006a. Anti-inflammatory activity of alkaloids: A twenty century review. Rev Bras Farmacogn 16: 109-139.

Barbosa-Filho JM, Medeiros KCP, Diniz MFFM, Batista LM, Athayde-Filho PF, Silva MS, Cunha EVL, Almeida JRGS, Quintans-Júnior LJ 2006b. Natural products inhibitors of the enzyme acetylcholinesterase. Rev Bras Farmacogn 16: 258-285

Blaszo G, Gaspar R, Gabor M, Ruve HJ, Rohdewald P 1996. Ace inhibition and hypotensive effect of procyanidins containing extract from the bark of Pinus pinaster Sol. Pharm Pharmacol Lett 6: 8-11.

Burnier M, Maillard M 2001. The comparative pharmacology of angiotensin II receptor antagonists. Blood Press 10(Suppl 1): 6-11.

Burt VL, Whelton P, Roccella EJ 1995. Prevalence of hypertension in the US adult population: results from the third National Health and Nutrition Examination Survey, 1988-1991. Hypertension 25: 305-313.

Bush K, Henry PR, Souser-Woehleke M, Trejo WH, Slusarchyk DS 1984. Phenacein - An angiotensin-converting enzyme inhibitor produced by a Streptomycete I. Taxonomy, fermentation and biological properties. $J$ Antibiot 37: 1308-1312.

Chen Y, Bean MF, Chambers C, Francis T, Huddleston MJ, Offen P, Westley JW, Carte BK, Timmerman BN 1991. Arrivacins, novel pseudoguaianolide esters with potent angiotensin II binding activity from Ambrosia psilostachya. Tetrahedron 47: 48694878.

Chen CH, Lin JY, Lin CN, Hsu SY 1992. Inhibition of angiotensin-I-converting enzyme by tetrahydroxyxanthones isolated from Tripterospermum lanceolatum. J Nat Prod 55: 691695.

Chen G, Wang X, Yu J, Li L 1996. Effects of gypenosides on hypoxic pulmonary vasoconstriction in healthy men an anesthetized dogs. Zhongguo Bingli Shengli Zazhi 12: 86-90.

Cho YJ, An BJ, Choi C 1993. Isolation and enzyme inhibition of tannins from Korean green tea. Han'Guk Saenghwa Hakhoe Chi 23: 216-223.

Chung O 1999. Angiotensin II receptor blockade and end-organ protection. Am J Hypertens 12(Pt 1-2): 150S-156S.

Crawford MH, Weber MA 1995. Cardiology clinics of North America. Washington: W.B. Saunders, 473-599.

Du X, Cruickshank K, McNamee R 1997. Case-control study of stroke and the quality of hypertension control in north west England. BMJ 314: 272-276.

Elbl G, Wagner H 1991. A new method for the in vitro screening of inhibitors of angiotensin-converting enzyme (ACE), using the chromophore- and fluorophorelabelled substrate, dansyltriglycine. Planta Med 57: 137-141.

Falcão HS, Lima IO, Santos VL, Dantas HF, Diniz MFFM, Barbosa-Filho JM, Batista LM 2005. Review of the plants with anti-inflammatory activity studied in Brazil. Rev Bras Farmacogn 15: 381-391.

Ferreira LAF, Henriques OB, Lebrun I, Batista MBC, Prezoto BC, Andreoni ASS, Zelnik R, Habernehl G 1992. A new bradykin-potentiating peptide (peptide P), isolated from the venom of Bothrops jararacussu (Jararacucu Tapete, Urutu Dourado). Toxicon 30: 33-40.

Ferreira SH 1965. A bradykinin-potentiating factor (BPF) present in the venom of Bothrops jararacussu. Brit J Pharmacol 24: 163-169.

Flack JM, Neaton J, Grimm RJr 1995. Multiple Risk Factor Intervention Trial Research Group. Blood pressure and mortality among men with prior myocardial infarction. Circulation 92: 2437-2445.

Fujimoto M, Mihara SI, Nakajima S, Ueda M, Nakamura M, 
Sakurai KS 1992. A novel non-peptide endothelin antagonist isolated from bayberry, Myrica cerifera. Febs Lett 305: 41-44.

Fuster V, Pearson TA 1996. 27th Bethesda Conference: Matching the intensity of risk factor management with the hazard for coronary disease events, September 1415, 1995. J Am Coll Cardiol 27: 957-1047.

Gonçalves MCR, Moura LSA, Rabelo LA, Barbosa-Filho JM, Cruz HMM, Cruz J 2000. Produtos naturais inibidores da enzima HMG CoA redutase. Rev Bras Farm 81: 63-71.

Grimm RHJr 1989 Alpha 1-antagonists in the treatment of hypertension. Hypertension 13(Suppl 1): 131-136.

Gustafsson F, Kobe L, Torp-Pedersen C, Hildebrandt P 1998. Influence of a history of arterial hypertension and pretreatment blood pressure on the effect of angiotensin converting enzyme inhibition after acute myocardial infarction. Trandolapril Cardiac Evaluation Study. J Hypertens 16(Suppl 1): S65S70.

Hall WD, Ferrario CM, Moore MA 1997. Hypertension-related morbidity and mortality in the southeastern United States. Am J Med Sci 313: 195-206.

Ham MS, Kims S, Hong JS, Lee JH, Chung EK, Park YS, Lee HY 1996. Screening and comparation of active substances of Angelica gigas Nakai produced in Kangwon and Angelica acutiloba Kitagawa produced in Japan. Sanop Misaengmul Hakhoe Chi 24: 624-629.

Han GQ, Pan JX, Li CL, Tu F 1991. The screening of Chinese traditional drugs by biological assay and the isolation of some active components. Int $J$ Chin Med 16: 1-17.

Hansen K 1995. In vitro screening for the detection of angiotensin converting enzyme (ACE) inhibitors in selected medicinal plants and identification of the active principles. Copenhagen, 116p. [Ph.D. Thesis - The Royal Danish School of Pharmacy, Copenhagen].

Hansen K, Nyman U, Smitt UW, Adsersen A, Gudiksen L, Rajasekharan S, Pushpangadan P 1995. In vitro screening of traditional medicines for anti-hypetrtensive effect based on inhibition of the angiotensin converting enzyme (ACE). $J$ Ethnopharmacol 48: 43-51.

Hansen K, Adsersen A, Christensen SB, Jensen SR, Nyman U, Smitt UW 1996a. Isolation of an angiotensin converting enzyme (ACE) inhibitor from Olea europaea and Olea lancea. Phytomedicine 319325.

Hansen K, Nyman U, Smitt UW, Adsersen A, Christensen SB, Schwartner C, Wagner H 1996b. Angiotensin converting enzyme (ACE) inhibitory flavonoids from Erythroxylum laurifolium. Phytomedicine 313-317.

Harris GH, Hoogsteen K, Silverman KC, Raghoobar SL, Bills GF, Lingham RB, Smith JL, Dougherty HW, Cascales C, Pelaez F 1993. Isolation and structure determination of pycnidione, a novel bistropolone stromelysin inhibitor from a Phoma sp. Tetrahedron 49: 2139-2144.

Hashimoto M, Hayashi K, Murai M, Fujii T, Nishikawa M, Kiyoto S, Okuhara M, Kohsaka M, Imanaka $\mathrm{H}$
1992. A novel tachykinin antagonist isolated from Streptomyces violaceusniger NO. 9326II. Biological and pharmacological properties of WS932. A tetrahydro-WS9329A (FK224). J Antibiot 45: 10641070.

Heintzen MP, Strauer BE 1994. Peripheral vascular effects of beta-blockers. Eur Heart J 15(Suppl C): 2-7.

Hensens OD, Zink D, Williamson JM, Lotti VJ, Chang RSL, Goetz MA 1991. Variecolin, a sesterterpenoid of novel skeleton from Aspergillus variecolor MF138. J Org Chem 56: 3399-3403.

Higashi Y, Oshima T, Ono N, Hiraga H, Yoshimura M, Watanabe M, Matsuura H, Kambe M, Kajiyama G 1995. Intravenous administration of L-arginine inhibts angiotensin-converting enzyme in humans. $J$ Clin Endocrinol Metab 80: 2198-2202.

Ikemizu S, Konishi H, Hataya C, Kishimoto M 1995. Preparation of angiotensin-converting enzyme inhibitor from mushroom grown of soybean skin. Patent-Japan Kokai Tokkyo Koho-07, 267, 975, 6PP.

Inokuchi JI, Okabe H, Yamauchi T, Nagamatsu A 1984. Inhibitors of angiotensin converting enzyme in crude drugs I. Chem Pharm Bull 32: 3615-3619.

Inokuchi JI, Okabe H, Yamauchi T, Nagamatsu A, Nonakada GI, Nishioka I 1985. Inhibitors of angiotensin converting enzyme in crude drugs II. Chem Pharm Bull 33: 264-269.

Inokuchi JI, Okabe H, Yamauchi T, Nagamatsu A, Nonaka GI, Nishioka I 1996a. Inhibitor of angiotensin converting enzyme. Life Sci 38: 1375-1382.

Inokuchi JI, Okabe H, Yamauchi T, Nagamatsu A, Nonaka GI, Nishioka I 1996b. Antihypertensive substance in seeds in Areca catechu L. Life Sci 38: 1375-1382.

Ishida K, Matsuda H, Murakami M 1998. Four new microginins, linear peptides from the cyanobacterium Microcystis aeruginosa. Tetrahedron 54: 13475-13484.

Izumitani Y, Yahara S, Nohara T 1990. Novel acyclic diterpene glycosides, capsianoisdes A-F and I-V, from Capsicum plants (Solanaceous studies. XIV). Chem Pharm Bull 38: 1299-1307.

Jonader M, Bastide J, Bastide P, Biko V, Carnat A, Lamaison JL 1989. Enzyme inhibiting activites in vitro and in vivo angiopropective activity of Viburnum opulus $\mathrm{L}$. Pharm Acta Helv 64: 94-96.

Kameda K, Takeku T, Okuda H, Kimura Y, Okuda T, Hatano T, Agata I, Arichi S 1987. Inhibitory effects of various flavanoids isolated from leaves of persimmon on angiotensin-conveting enzyme activity. $J$ Nat Prod 50: 680-683

Kanetoshi A, Hayashi T, Anetal M, Kaneshima H, Otani M, Minoshima H, Uchivama T, Hatakevama Y, Iida O 1993. Study on the inhibitory effect of Angelicae radix on angiotensin I converting enzyme (ACE) activity as a measure for its optium preparation. Hakkaidoritsu Elsei Kenkyoshoho 43: 1-5.

Kaplan NM 1996. Diuretics: cornerstone of antihypertensive therapy. Am J Cardiol 77: 3B-5B.

Kase H, Kaneko M, Yamada K 1987. A novel inhibitor of angiotensin I converting enzyme produced by Micromonospora halophytica subsp. exilisia I. Fermentation, isolation and biological properties. $J$ Antibiot 40: 450-454.

Kido Y, Hamakado T, Yoshida T, Anno M, Motoki Y, Wakamiya 
T, Shiba T 1983. Isolation and characterization of ancovenin, a new inhibitor of angiostensin I converting enzyme, produced by Actinomycetes. $J$ Antibiot 36: 1293-1299.

Kido Y, Hamakado T, Anno M, Miyagawa E, Motoki Y, Wakamiya T, Shiba T 1984. Isolation and characterizacion of $15 \mathrm{~B} 2$, a new phosphorus containing inhibitor of angiotensin I converting enzyme produced by Actinomadura sp. $J$ Antibiot 37: 965-969.

Kido Y, Hamakado T, Abu M, Miyagawa E, Motoki Y 1985. Angiotensi-converting enzyme inhibitor 15B2 from Actinomycetes. Patent-Japan Kokai Tokkyo Koho60, 145, 091, 6PP.

Killday KB, Longley R, McCarthy JP, Pomponi SA., Wright AE, Neale RF, Sills MA. Sesquiterpene-derived metabolites from the deep water marine sponge Poecillastra sollasi. J Nat Prod 56: 500-507.

Kimoto K, Kuroda Y, Saito Y, Yamamoto J, Murakami T, Aoyagi Y 1998. Purification and identification of angiotensin I-converting enzyme inhibitor from Morokheiya (Corchorus olitorius). Food Sci Technol Int 4: 223-226.

Kinoshita E, Yamakoshi J, Kikuchi M 1993. Purification and identification of an angiotensin I-coverting enzyme inhibitor from soy sauce. Biosci Biotech Biochem 57: 1107-1110.

Komori Y, Sugihara H 1990. Characterization of a new inhibitor for angiotensin converting enzyme from the venom of vipera Aspis aspis. Int J Biochem 22: 767-771.

Koyama F, Nakamura Y 1993. Antihypertensives and healthy foods containing tripeptide. Patent-Japan Kokai Tokkyo Koho-05, 97, 798, 6PP.

Krassnigg F, Placzek R, Engl R, Frick J, Schill WB 1984. Inhibition mechanism of trifluoperazine and gossypol on human sperm motility. Contraceptive Delivery Systems 5: 15-16.

Krumholz HM, Parent EM, Tu N 1997. Readmission after hospitalization for congestive heart failure among medicare beneficiaries. Arch Intern Med 157: 99104.

Kumar KV, Das UN 1993. Are free radicals involved in the pathobiology of human essential hypertension? Free Radical Res Commun 19: 59-66.

Lafranconi WM, Huxtable RJ 1983. Changes in angiotensinconverting enzyme activity in lungs damaged by the pyrrolizidine alkaloid monocrotaline. Thorax 38: 307-309.

Lam YKT, Williams-Jr DL, Sigmund JM, Sanchez M, Genilloud O, Kong YL, Stevens-Miles S, Huang L, Garrity GM 1992. Cochinmicins, novel and potent cyclodepsipeptide endothelin antagonist from a Microbispora sp. I. Production, isolation, and characterization. J Antibiot 45: 1709-1716.

Lasagna L 2000. Diuretics vs alpha-blockers for treatment of hypertension: lessons from ALLHAT. Antihypertensive and lipid-lowering treatment to prevent heart attack trial. JAMA 283: 2013-2014.

Lazarus JM, Bourgoignie JJ, Buckalew VM 1997. For the modification of diet in renal disease study group. Achievement and safety of a low blood pressure goal in chronic renal disease. Hypertension 29: 641-650.
Lee HS, Oh WK, Choi HC, Lee JW, Kang DO, Park CS, Mheen TI, Ahn JS 1998. Inhibition of angiotensin II receptor binding by quinolone alkaloids from Evodia rutaecarpa. Phytother Res 12: 212-214.

Lee SD, Hwang WK, Okuda H 1996. Effect of acidic polysaccharide of Korean ginseng on lipolytic action of toxiohormone- $\mathrm{L}$ and on activity of angiotensin-converting enzyme. Korean J Ginseng Sci 20: 248-255.

Leem JY, Yook CS 1990. Studies on the chemical components and angiotensin coverting enzyme inhitory activity of Korean Acanthopanax divaricatus seem. Korean J Pharmacogn 21: 250-252.

Lin JY, Chen TS, Chen CS 1994. Flavonoids as nonpeptide angiotensin-converting enzyme inhibitors for hypertension treatment. Patent-Japan Kokai Tokkyo Koho-06, 135, 830, 16PP.

Maeda I, Kato T, Tani A, Aoyagi H, Kihara H, Ohno M 1993. Characterization of peptides isolated from Trimeresurus flavoviridis and Trimeresurus okinavensis venoms. Bull Chem Soc Japan 66: 1509-1511.

Maruyama S, Miyoshi S, Tanaka H 1989. Angiotensin Iconverting enzyme inhibitors derived from Ficus carica. Agr Biol Chem 53: 2763-2767.

Maruyama S, Tanaka H, Maeda H, Mitsuyoshi S, Kaneko T, Yoshizawa Y, Fukui F 1990. Isolation of oligopeptides from sap and fruits of a fig tree as antihypertensive agents. Patent-Japan Kokai Tokkyo Koho-02, 282, 394, 9PP.

Melzig MF, Pieper S, Siems WE, Heder G, Bottger A, Liberra $\mathrm{K}$, Lindequist U 1996. Screening of selected basidiomycetes of inhitory activity on neutral endopeptidase (NEP) and angiotensin-converting enzyme (ACE). Pharmazie 51: 501-503.

Meunier MT, Villie F, Jonadet M, Bastide J, Bastide P 1987. Inhibitors of angiotensin converting enzyme by flavanolic compounds: in vitro and in vivo studies. Planta Med 53: 12-15.

Mikami Y, Suzuki T 1983. Novel microbial inhibitors of angiotensin-converting enzyme, aspergillomarasmines A and B. Agr Biol Chem 47: 2693-2695.

Mitane SY, Suguire T, Miwa Y, Yamaguchi K, Kyuki K 1996. Effect of tea-leaf saponin on blood pressure of spontaneously hypertensive rats. Yakugaku Zasshi 116: 388-395.

Miyata S, Hashimoto M, Fujie K, Nishikawa M, Kiyoto S, Okuhara M, Kohsaka M 1992. New endothelin receptor antagonists isolated from Streptomcyes sp. NO. 7338. II. Biological characterization and pharmacological characterization of WS-7338 B. $J$ Antibiot 45: 83-87.

Molteni A, Ward WF, Ts'Ao CH, Port CD, Solliday NH 1984. Monocrotaline-induced pulmonary endothelial dysfunction in rats. Proc Soc Exp Biol Med 176: 88-94.

Momose Y, Nimura M, Arisawa M, Hayashi T, Takeda R, Nakanashi S 1994. Hypotensive activity of ovatodiolides isolated from a Chinese crude drug "Fang Feng Cao". Phytother Res 8: 482-484.

Morais LCSL, Barbosa-Filho JM, Almeida RN 2003. Plants and bioactives compounds for the treatment of 
Parkinson's desease. Arquivo de Fitomedicina 1: 127-132.

Morishita Y, Sano T, Ando K, Saitoh Y, Kase H, Yamada K, Matsuda Y 1991. Microbial polysaccharide HS142-1, competitively and selectively inhibits and binding to its guanylyl cyclase-containing receptor. Biochem Biophys Res Commun 176: 994-997.

Morita H, Yoshida N, Takeya K, Itokawa H, Shirota O 1996. Configuration and conformational analyses of a cyclic octapeptide, Lyciumin A, from Lycium chinese Mill. Tetrahedron 52: 2795-2802.

Morota T, Sasaki H, Chin M, Sato T, Katayma N, Fukuyama K, Mitsuhashi H 1987. Studies on the crude drug containing the angiotensin-I converting enzyme inhibitors on the active principles of Lycium chinense Muller. Shoyakugaku Zasshi 41: 169-173.

Moser M, Hebert PR (1996) Prevention of disease progression, left ventricular hypertrophy and congestive heart failure in hypertension treatment trials. $\mathrm{J} \mathrm{Am} \mathrm{Coll}$ Cardiol 27: 1214-1218

Moura MD, Torres AR, Oliveira RAG, Diniz MFFM, BarbosaFilho JM 2001. Natural products inhibitors of models of mammary neoplasia. Brit J Phytotherapy 5: $124-145$

Moura MD, Silva JS, Oliveira RAG, Diniz MFFM, BarbosaFilho JM 2002. Natural products reported as potential inhibitors of uterine cervical neoplasia. Acta Farm Bonaerense 21: 67-74.

Mynderse JS, O'Connor SC, Nakatsukasa WM 1984. Enzyme inhibitors. Patent-Eur-103, 403, 52PP

Mynderse JS, Samlaska SK, Fukuda DS, Du-Bus RH, Baker PJ 1985. Isolation of A58365A and A58365B, angiotensin converting enzyme inhibitors produced by Streptomyces chromofuscus. J Antibiot 38: 10031007.

National Heart, Lung, and Blood Institute 1997. Fact Book Fiscal Year 1996. Bethesda, MD: U.S. Department of Health and Human Services, National Institutes of Health.

Neaton JD, Grimm RHJr, Prineas RJ 1993. For the Treatment of Mild Hypertension Study Research Group. Final results. JAMA 270: 713-724.

Niitsu K, Ikeya Y, Sato T, Katayama N, Fukuyama K, Chin M, Taguchi H, Mitsuhashi H 1987. Studies on the crude drug containing the angiotensin I converting enzyme inhibitors. (II). On the active principles of Frittilaria verticillata willdenow var. thumbergii Baker. Shoyakugaku Zasshi 41: 174-179.

O'Connor S, Somers P 1985. Methods for the detection and quantitation of angiotensin converting enzyme inhibitors in fermentation broths. $J$ Antibiot 38: 993-996.

Ogino T, Sato S, Sasaki H, Chin M 1986. Isolation and structure determination of 1,3,4-tridehydrofangchinolium hydroxide. Patent-Japan Kokai Tokkyo Koho-62, 294, 684, 5PP.

Ogino T, Sato S, Sasaki H, Chin M 1987a. Angiotensin I converting enzyme inhibiting activity of tetrandrine, fangchinoline and derivatives thereof and pharmaceutical compositions containing them. Patent-Japan Kokai Tokkyo Koho-62, 207, 216, $11 \mathrm{PP}$.

Ogino T, Sato S, Sasaki H, Chin M 1987b. Isolation of new alkaloids from Stephania tetrandra as antihypertensives. Patent-Japan Kokai Tokkyo Koho-62, 205, 084, 5PP.

Ogino T, Katsuhara T, Sato T, Sasaki H, Okada M, Maruno M 1998. New alkaloids from the root of Stephania tetrandra (Fen-Fang-JI). Heterocycles 48: 311-317.

Oh WK, Kang DO, Park CS, Ahn SC, Ko HR, Kim BY, Mheen TI, Ahn JS, Lee HS 1997. Screening of the angiotensin II antagonists from medicinal plants. Korean J Pharmacogn 28: 26-34.

Okamot Y, Yoshizawa T 1994. Angiotensin-converting enzyme inhibitors and aldose reductase inhibitors containing Passiflora quadrangularis extracts or vitexin. Patent-Japan Kokai Tokkyo Koho-06, 293, 657, 4PP.

Okamura K, Iwakami S, Matsunaga T 1992 Biological activity of monoterpenes. Toyama-Ken Yakuji Kenkyusho Nenpo 20: 95-101.

Okino T, Matsuda H, Murakami M, Yamaguchi K 1993. Microginin, an angiotensin-converting enzyme inhibitor from the blue-green alga Microcystis aeruginosa. Tetrahedron Lett 34: 501-504.

Olafsson K, Jaroszewski JW, Smitt UW, Nyman U 1997. Isolation of angiotensin converting enzyme (ACE) inhibiting triterpenes from Schinus molle. Planta Med 63: 352-355.

Ondetti MA, Rubin B, Cushman DW 1997. Design of specific inhibitiors of angiotensin-converting enzyme new class of orally active antihypertensive agents. Science 196: 441-443.

Packer L, Rimbach G, Virgili F 1999. Antioxidant activity and biologic properties of a procyanidin-rich extract from pine (Pinus maritima) bark, pycnogenol. Free Radical Biol Med 37: 704-724.

Parnas BL, Durley RC, Rhoden EE, Kilpatrick BF, Makkar N, Thomas KE, Smith WG, Corley DG 1996. Isolation and structure of leukotriene-A-4 hydrolase inhibitor: 8(S)-amino-2(R)-methyl-7-oxononanoic acid produced by Streptomyces. J Nat Prod 59: 962964.

Pereira JV, Modesto-Filho J, Agra MF, Barbosa-Filho JM 2002. Plant and plant-derived compounds employed in prevention of the osteoporosis. Acta Farm Bonaerense 21: 223-234.

Psaty BM, Smith NL, Siscovick DS 1997. Health outcomes associated with antihypertensive therapies used as first-line agents: a systematic review and metaanalysis. JAMA 277: 739-745.

Rocha LG, Almeida JRGS, Macedo RO, Barbosa-Filho JM 2005. A review of natural products with antileishmanial activity. Phytomedicine 12: 514-535.

Sakurai T, Yamada H, Saito KI, Kano Y 1993. Enzyme inhibitory activities of acetylene and sesquiterpene compounds in Atractylodes rhizome. Biol Pharm Bull 16: 142-145.

Sanz MJ, Terencio MC, Paya M 1993. Pharmacological actions of a new procyanidin polymer from Pistacia lenticus L. Pharmazie 48: 152-153.

Sauru MD, Camporesi DA, Sudakow RL 1995. The antitumor agent, taxol, attenuates contractile activity in rat aortic smooth muscle. Life Sci 56: 157-161.

Scholkens BA, Gehring D, Scholotte V, Weithmann U 1982 Evening primrose oil, a dietary prostaglandin 
precursor, diminishes vascular reactivity to renin and angiotensin II in rats. Prostraglandin Leukotrienes Med 8: 273-285.

Sendl A, Elbl G, Steinke B, Redl K, Breu W, Wagner H 1992. Comparative pharmacological investigations of Allium ursinum and Allium sativum. Planta Med 58: $1-7$

Shimizu E, Hayashi A, Takahashi R, Aoyagi Y, Murakami T, Kimoto K 1999. Effects of angiotensin-I converting enzyme inhibitor from Ashitaba (Angelica keiskei) on blood pressure of spontaneously hypertensive rats. J Nutr Sci Vitamol 45: 375-383.

Silva JS, Moura MD, Oliveira RAG, Diniz MFFM, BarbosaFilho JM 2003. Natural products inhibitors of ovarian neoplasia. Phytomedicine 10: 221-232.

Singer DRJ, Markandu ND, Cappuccio FP, Miller MA, Sagnella GA, Macgregor GA 1995. Reduction of salt intake during converting enzyme inhibitor treatment compared with addition of a thiazide. Hypertension 25: 1042-1044.

Singh PD, Johnson JH 1984. Muraceins-muramyl peptides produced by Nocardia orientalis as angiotensiconverting enzyme inhibitors. II. Isolation and structure determination. J Antibiot 37: 336-343.

Somanadhan B, Smitt UW, George V, Pushpangadan P, Rajasekharan S, Duus JO, Nyman U, Olsen CE, Jaroszewski JW 1998. Angiotensin converting enzyme (ACE) inhitors from Jasminum azoricum and Jasminum graniflorum. Planta Med 64: 246250.

Stamler J 1991. Blood pressure and high blood pressure: aspects of risk. Hypertension 18(Suppl I): 95-107.

Stevens-Miles S, Goetz MA, Bills GF, Giacobre RA, Tkacz JS, Chang RSL, Mojena M, Martin I, Diez MT, Pelaez F, Hensens OD, Jones T, Burg RW, Kong YL, Huang LY 1996. Discovery of an antiotensin II binding inhibitor from a Cytospora $s p$. using semiautomated screening procedures. $J$ Antibiot 49: 119123.

Sutter MC, Wang YX 1993. Recent cardiovascular drugs from Chinese medicinal plants. Cardiovasc Res 27: 18911901.

Takai S, Sakaguchi M, Jin D, Baba K, Miyazaki M 1999. Effects of daphnodorin A, daphnodorin B and daphnodorin C on human chymase-dependent angiotensin II formation. Life Sci 64: 1889-1896.

Takashari T, Sato T, Kaneshima H 1993. Inhibitor of angiotensin converting enzyme from Acathopanax senticosus. Hokkaidoritsu Eisei Kenkyusho Ho 43: 63-64.

The 1988 Report of the Joint National Commitee on Detection, Evaluation, and Treatment of High Blood Pressure. Arch Int Med 148: 1023-1038.

Tsi D, Tan BKH 1997. Cardiovascular pharmacology of 3-Nbutylphthalide in spontaneously hypertensive rats. Phytother Res 11: 576-582.

Uchida S, Ikari N, Ohta H, Niwa M, Nonaka GI, Nishioka I, Ozaki M 1987. Inhibitory effects of condensed tannins on angiotensin converting enzyme. Jap $J$ Pharmacol 43: 242-246.

Ueno H, Horie S, Nishi Y, Shogawa H, Kawasaki M, Suzuki S, Hayashi T, Arisawa M, Shimizu M, Yoshizaki M, Morita N 1988. Chemical and pharmaceutical studies on medicinal plants in Paraguay. Geraniin, an angiotensin-converting enzyme inhibitor from "Paraparai mi", Phyllanthus niruri. J Nat Prod 51: 357-359.

VillarA, Paya M, Terencio MC 1986. Plants with antihypertensive action. Fitoterapia 57: 131-145.

Waeber B 1998. The place of ACE inhibition in the modern therapeutic era: beyond blood pressure control Introduction. $J$ Cardiovasc Pharmacol,32(Suppl 2): 5-6.

Wagner H, Elbl G, Lotter H, Guinea M 1991. Evaluation of natural products as inhibitors of angiotensin Iconverting enzyme (ACE). Pharm Pharmacol Lett 1: $15-18$.

Wagner H, Elbl G 1992. ACE-inhibitory procyanidins from Lespedeza capitata. Planta Med 58: 297-298.

Wakamiya T, Ueki Y, Shiba T, Kido Y, Motoki Y 1985. The structure of ancovenin, a new peptide inhibitor of angiotensin I converting enzyme. Tetrahedron Lett 26: 665-668

Wallin BG, Frisk-Holmberg M 1981. The antihypertensive mechanism of clonidine in man. Evidence against a generalized reduction of sympathetic activity. Hypertension 3: 340-346.

Wenzel RR, Bruck H, Noll G, Schafers RF, Daul AE, Philipp T 2000. Antihypertensive drugs and the sympathetic nervous system. J Cardiovasc Pharmacol $35(7$ Suppl. 4): S43-S52.

Williams LAD, Gossell-Williams M, Barton EN, Fleischhacker R 1997. Angiotensin converting enzyme inhibiting and anti-dipsogenic activities of Euphorbia hirta extracts. Phytother Res 11: 401-402.

Yahara M, Nohara T, Irino N, Okueda H, Izumitani Y 1990. Isolation of diterpenoid glycosides, capsianosides, from Capsicum as antihypertensive agents. PatentJapan Kokai Tokkyo Koho-02, 138, 289, 14PP.

Yahara S, Shigeyama C, Nohara T, Okuda H, Wakamatsu K, Yasuhara T 1989. Structures of anti-ACE and renin peptides from Lycii radicis cortex. Tetrahedron Lett 30: 6041-6042.

Yahara S, Shigeyama C, Ura T, Wakamatsu K, Yasuhara T, Nohara T 1993. Ciclic peptides, acyclic diterpene glycosides and other compounds from Lycium chinense Mill. Chem Pharm Bull 41: 703-709.

Yamadaki M, Shimoyama A 1992. Angiotensin-converting enzyme I inhibitor extraction from the Eucommia ulmoides leaves. Patent-Japan Kokai Tokkya Koho04, 368, 336, 5PP.

Yamahara J, Kobayashi G, Iwamoto M, Matsuda H, Fujimura H 1989. The effect of alismol isolated from Alismatis rhizoma on experimental hypertensive models in rats. Phytother Res 3: 57-60.

Yamato M, Koguchi T, Okachi R, Yamada K, Nakayama K, Kase H, Karasawa A, Shuto K 1986. A novel inhibitor of angiotensin I converting enzyme produced by an Actinomycete K-26. J Antibiot 39: 44-52.

Yeung BKS, Nakao Y, Kinnel RB, Carney JR, Yoshida WY, Scheuer PJ, Kelly-Gorges M 1996. The kapakahines, cyclic peptides from the marine sponge Cribrochalina olemda. J Org Chem 61: $7168-7183$.

Zannad F 2000. The potential advantages of a modern antihypertensive therapy in the elderly. JCardiovasc Pharmacol 35(3 Suppl. 1): S19-23. 


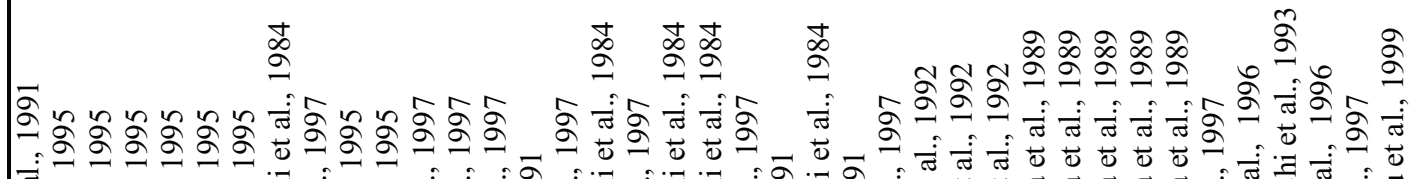

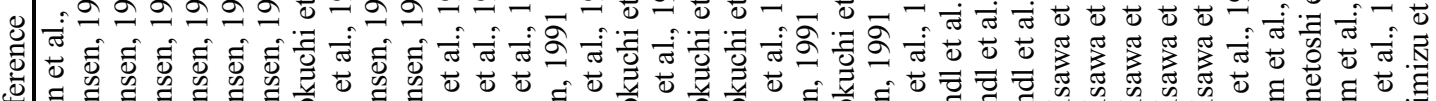

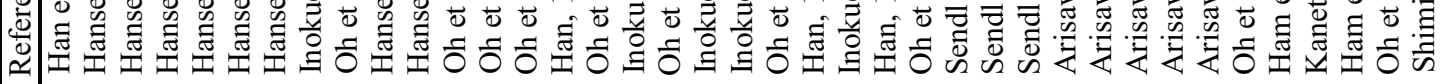

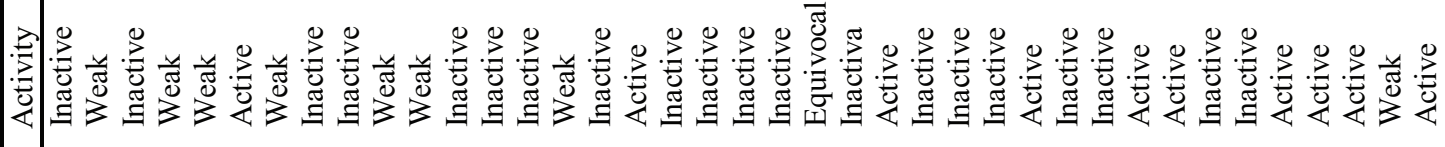

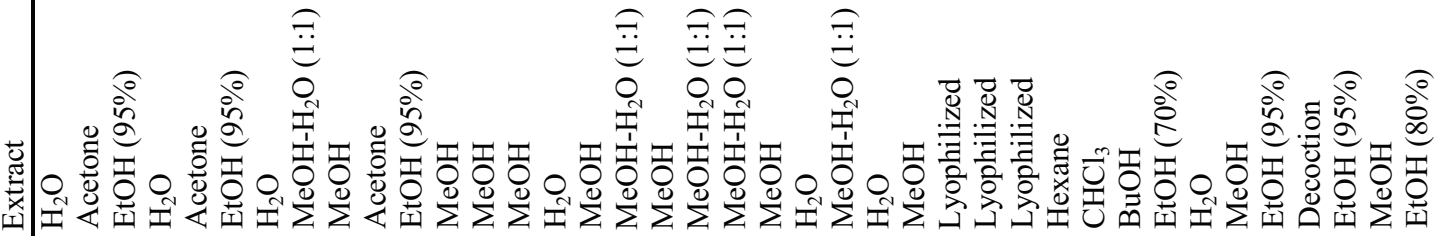

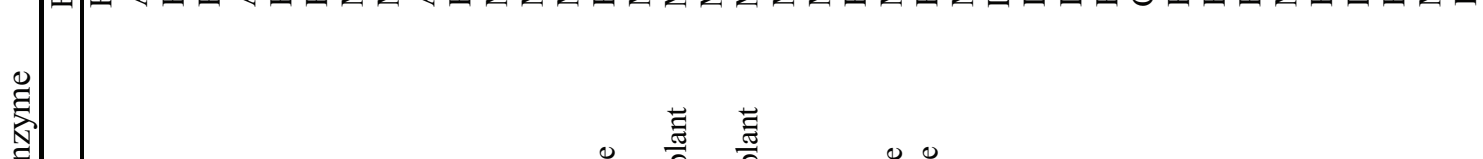

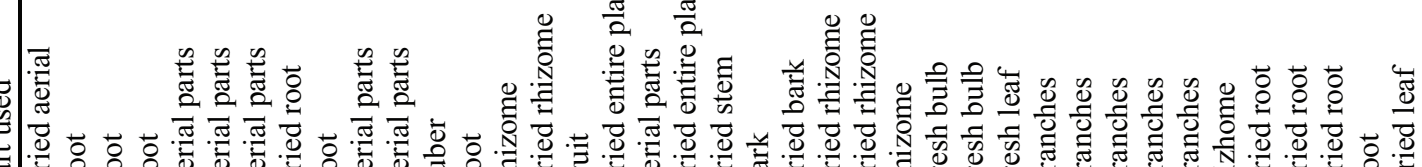

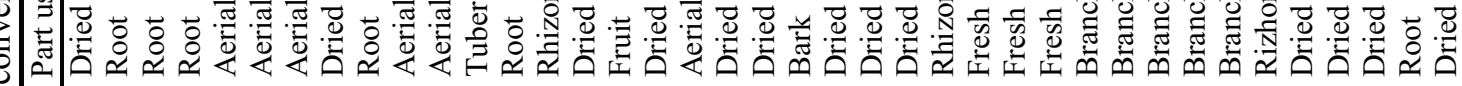
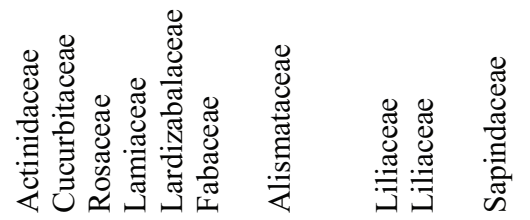

II

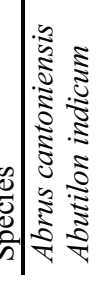
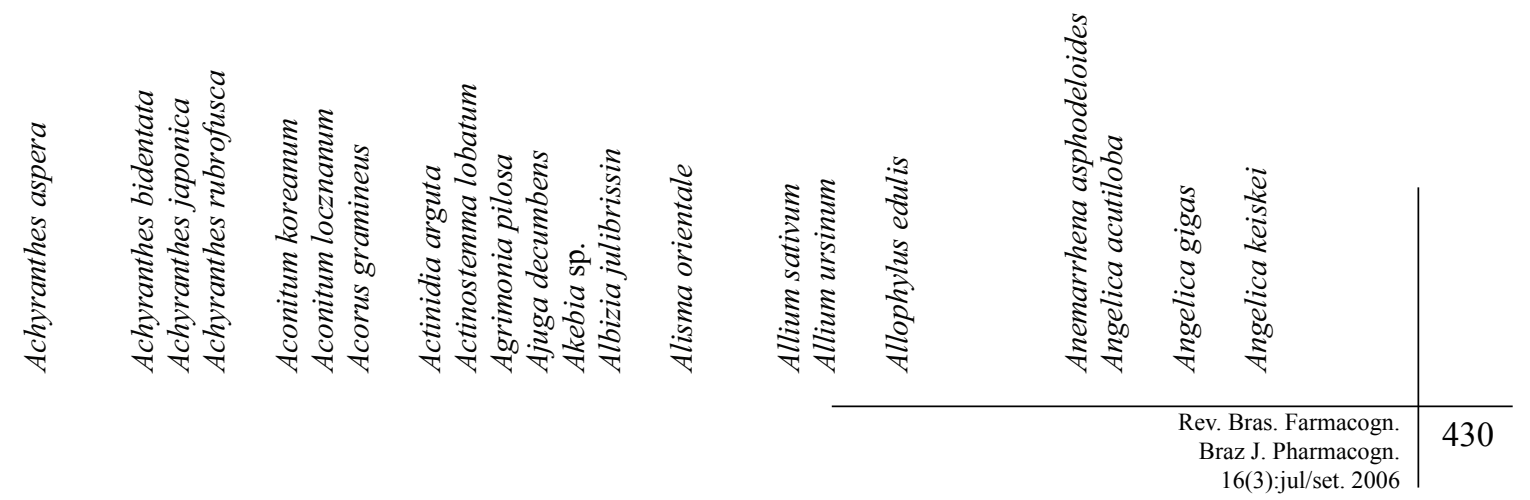


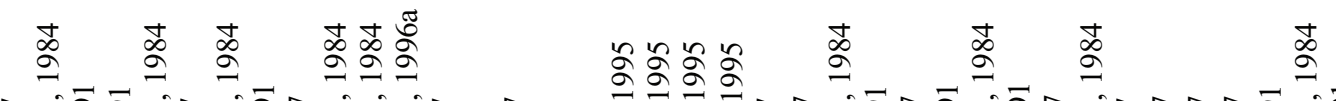

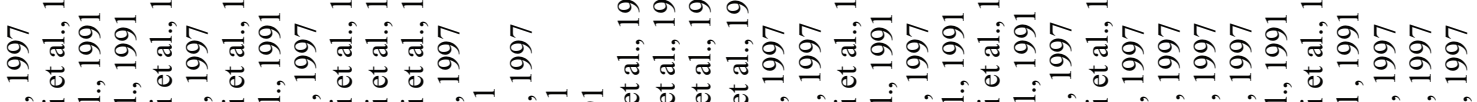

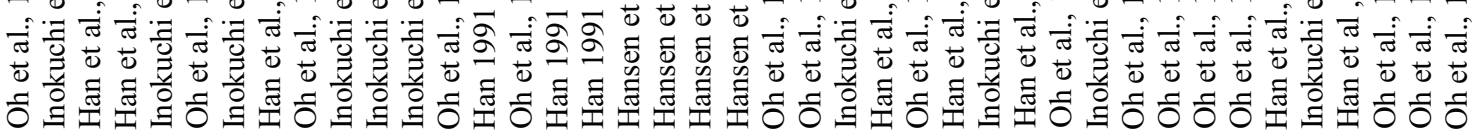

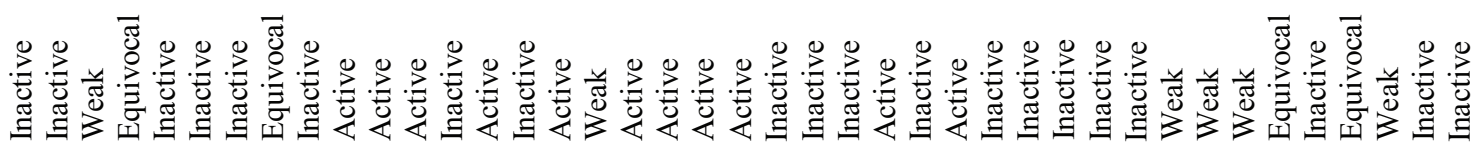

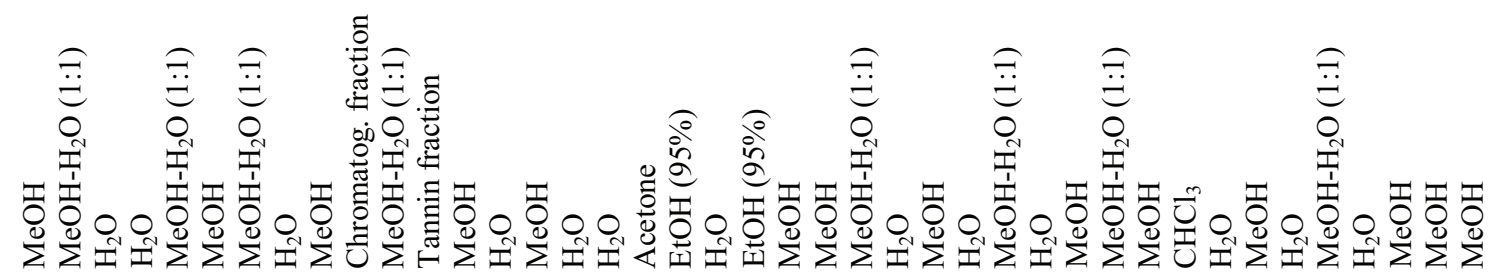

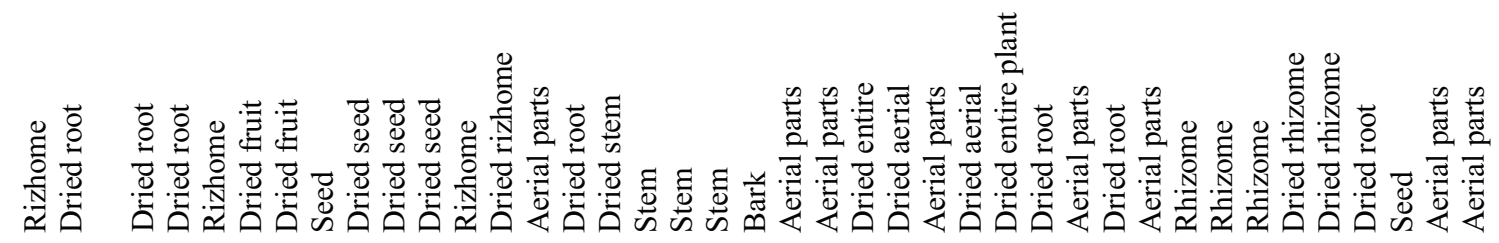

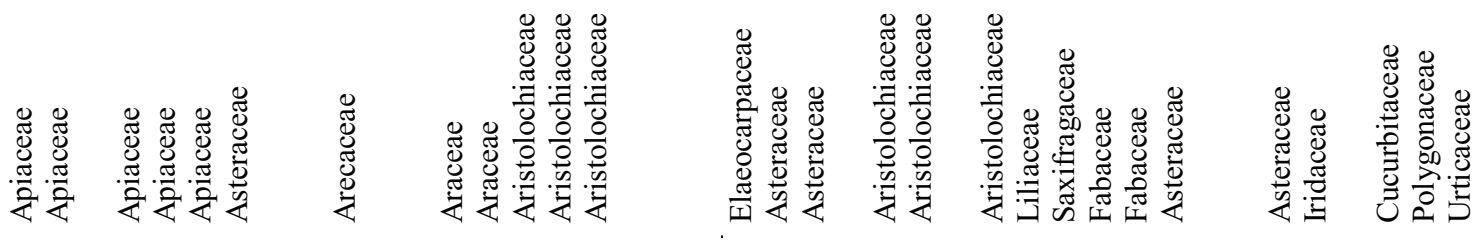

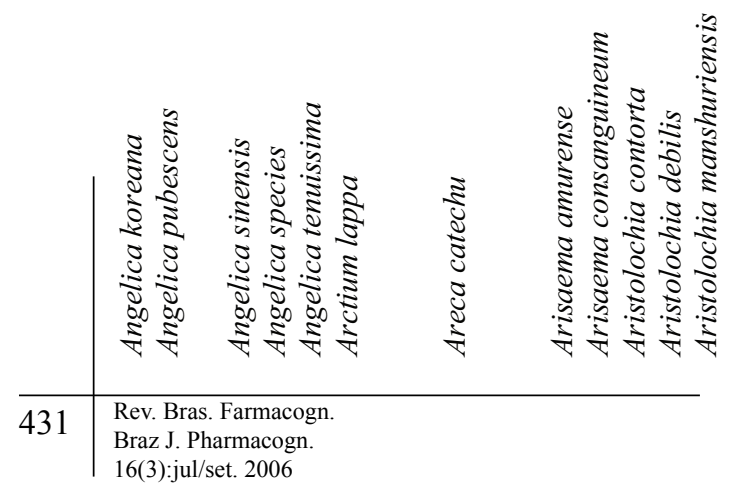

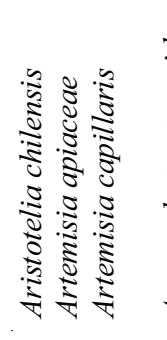

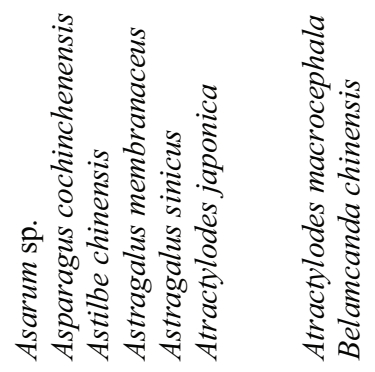

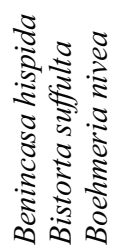




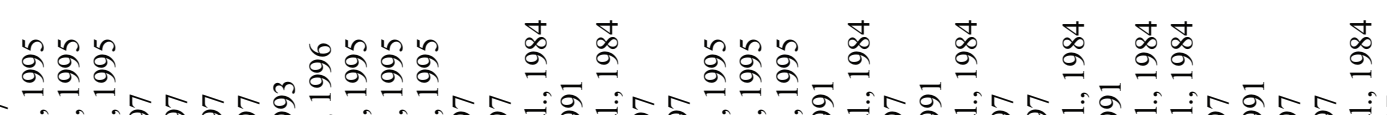

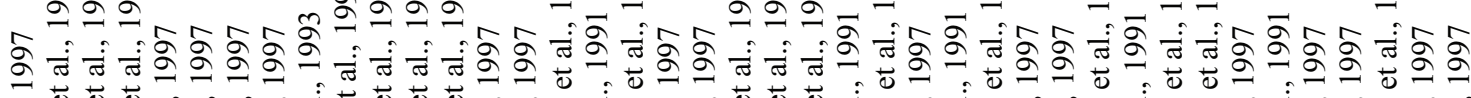

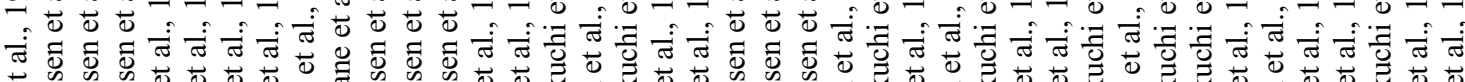

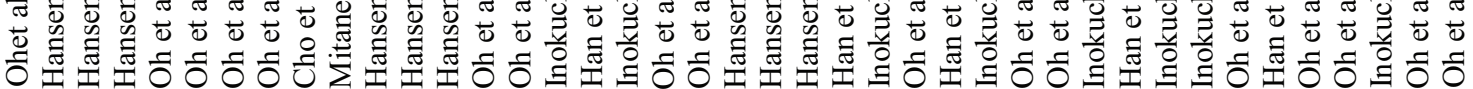

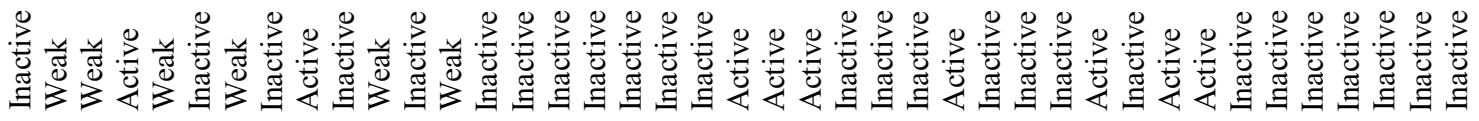

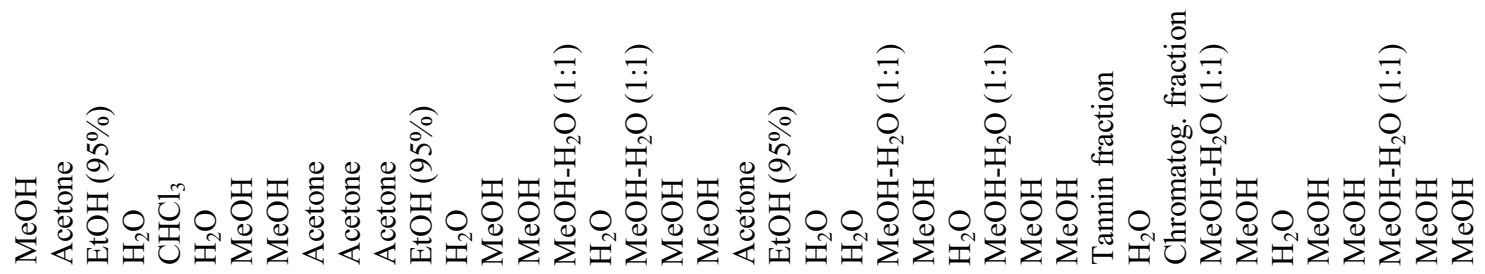

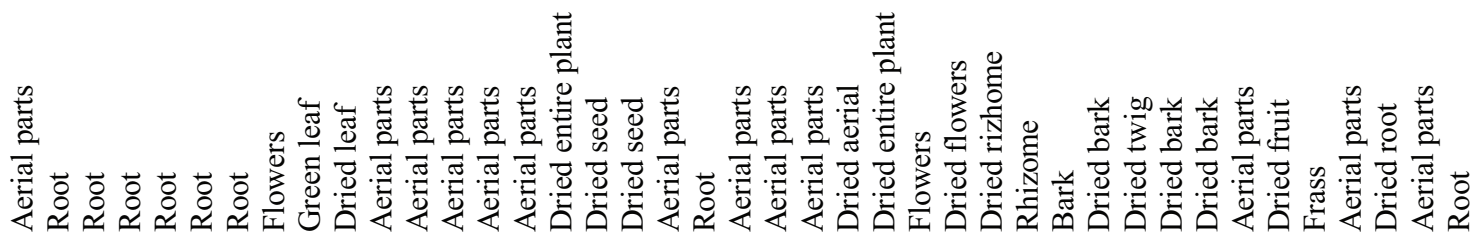

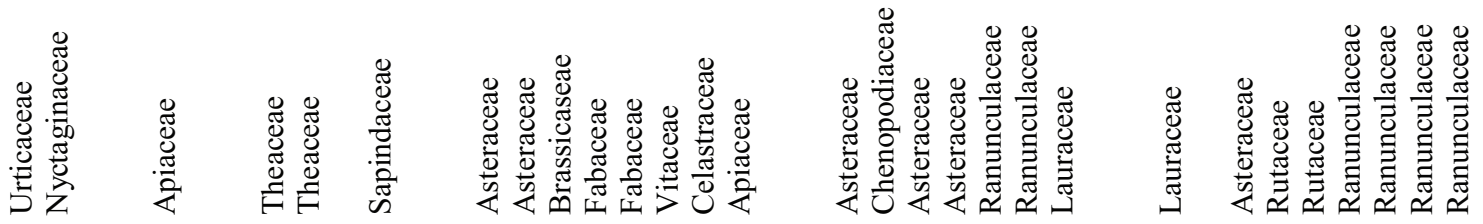

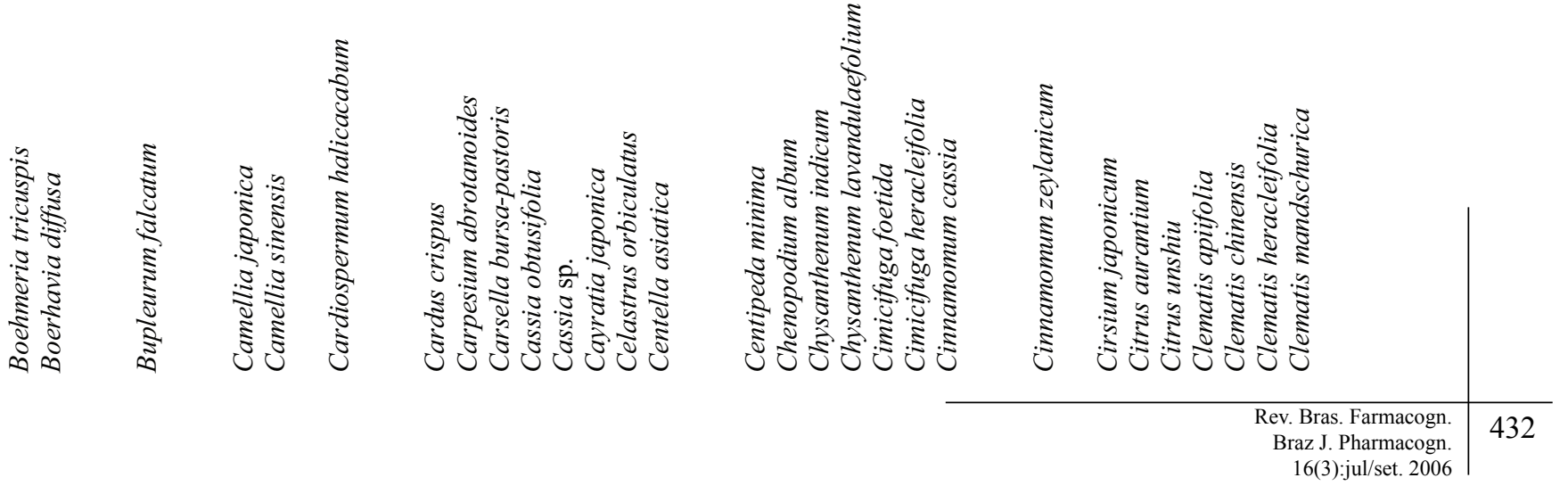




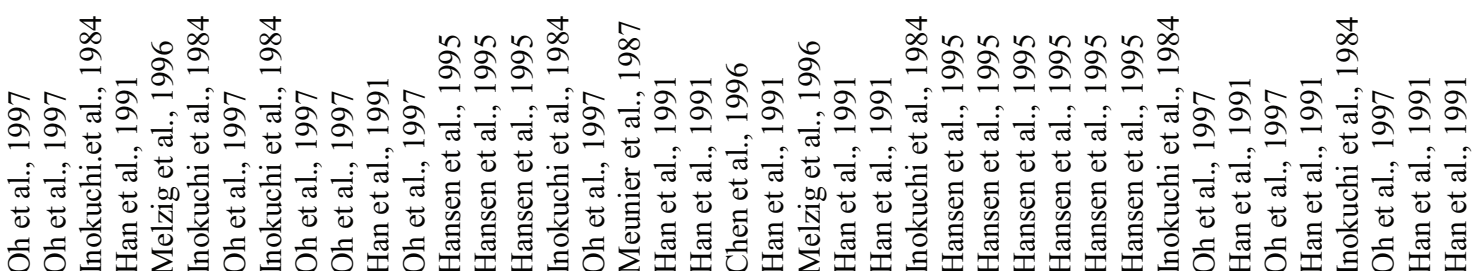

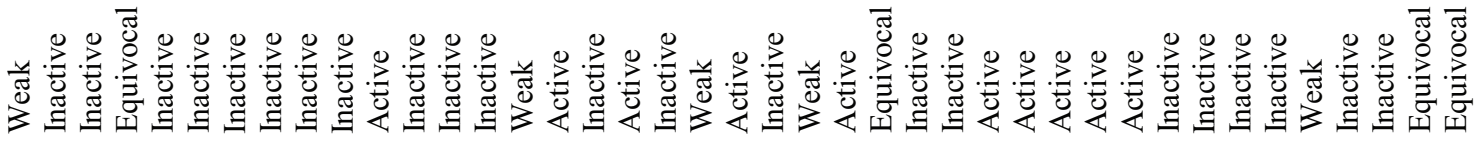

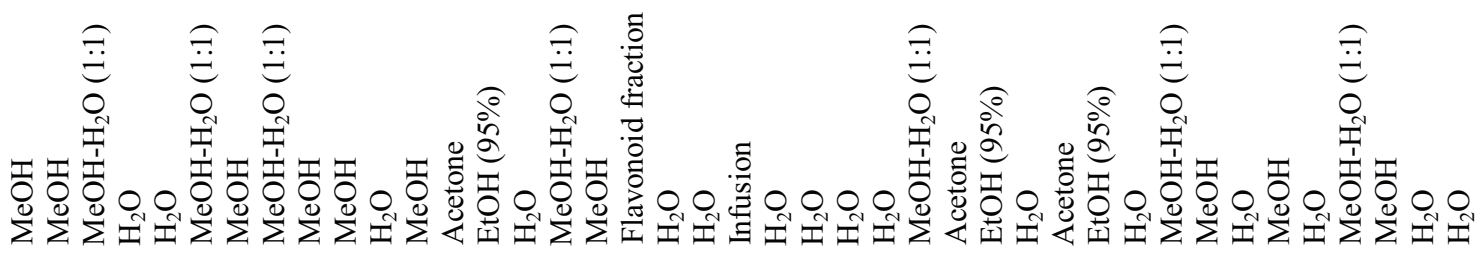

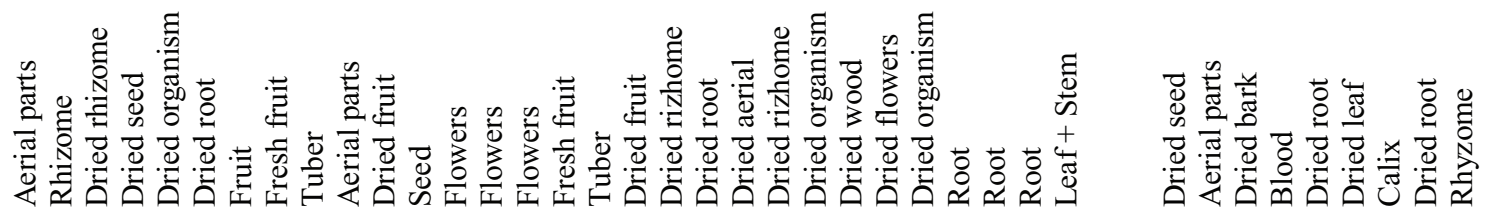
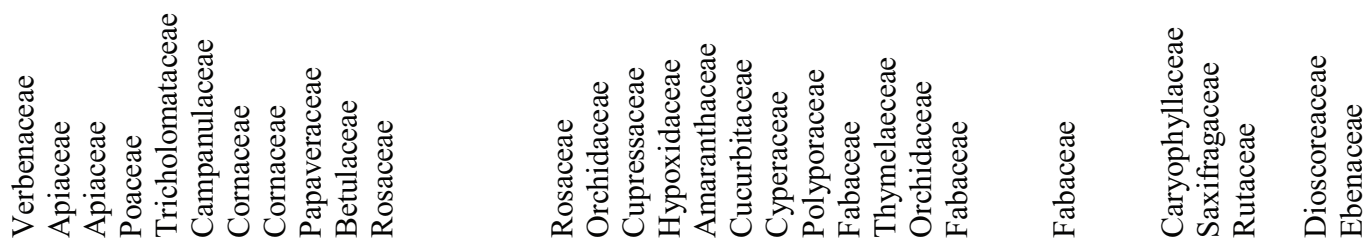

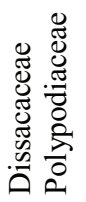
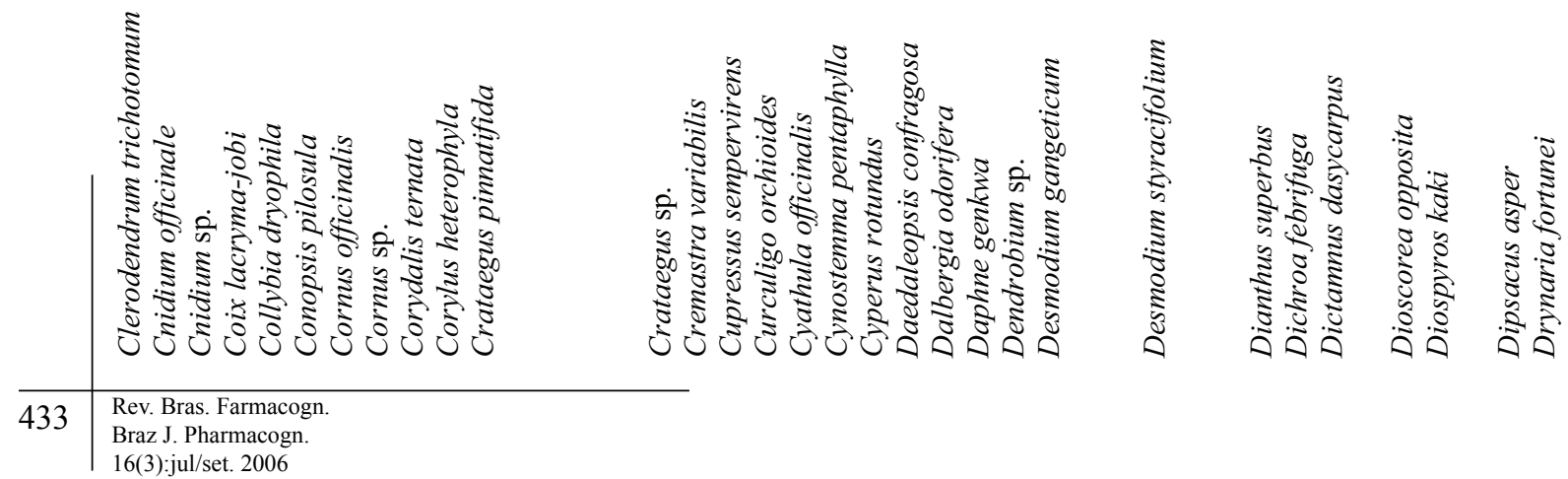


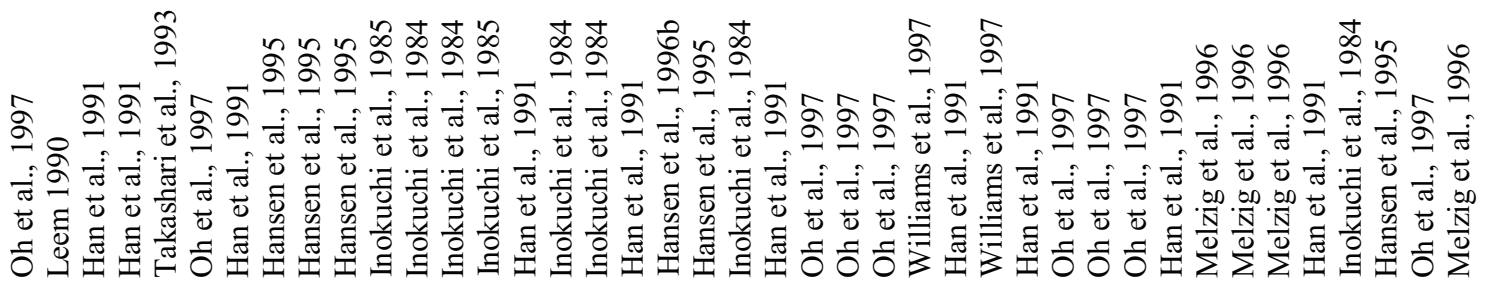

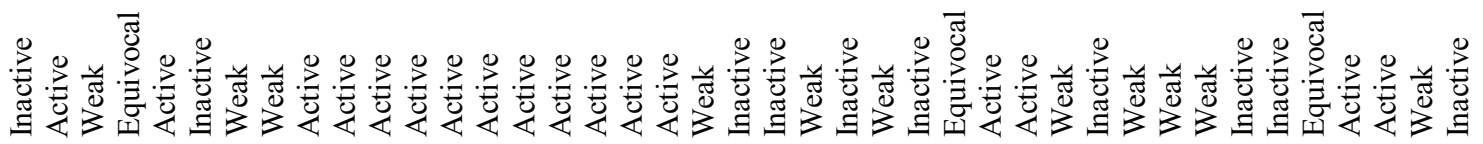

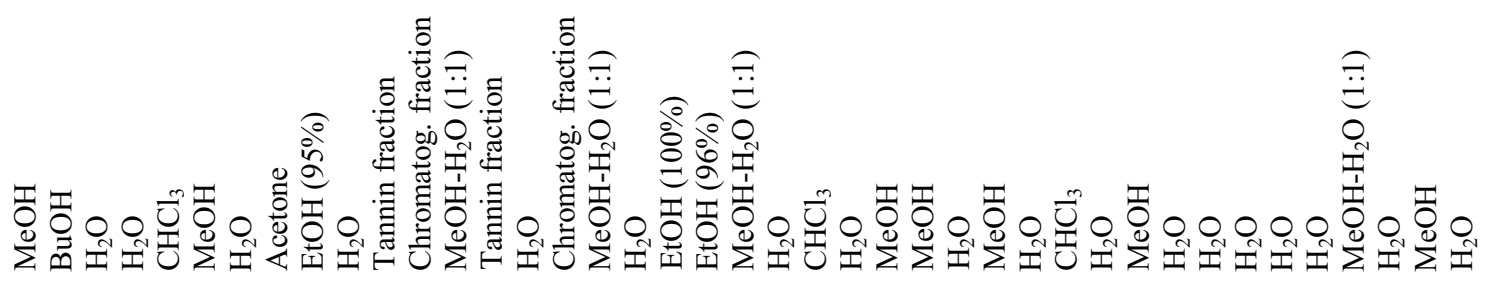

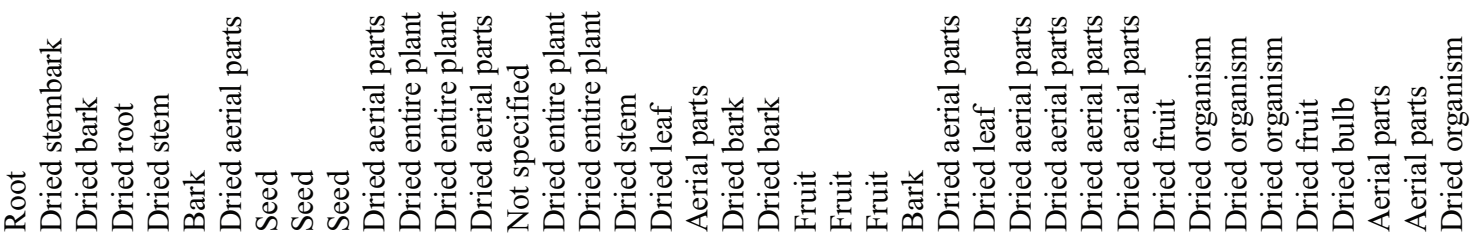
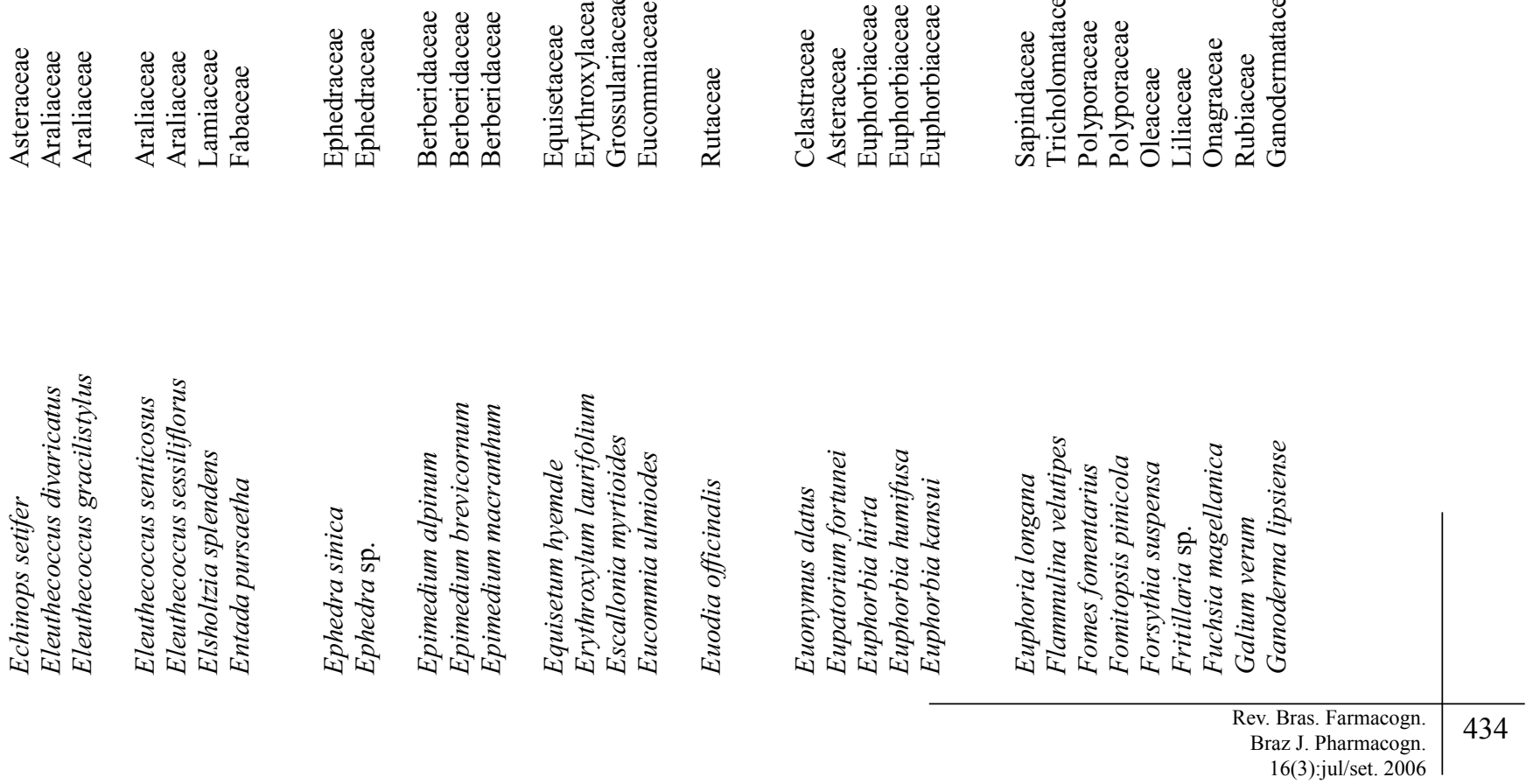


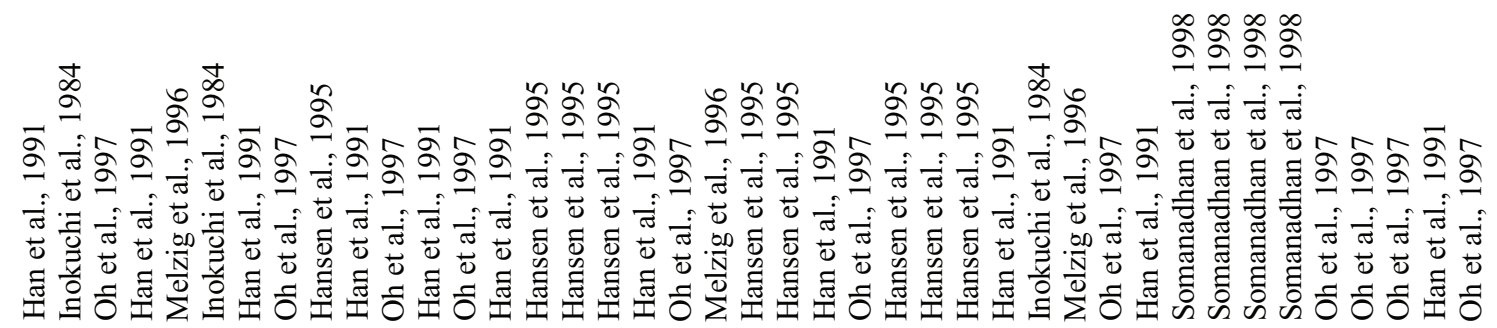

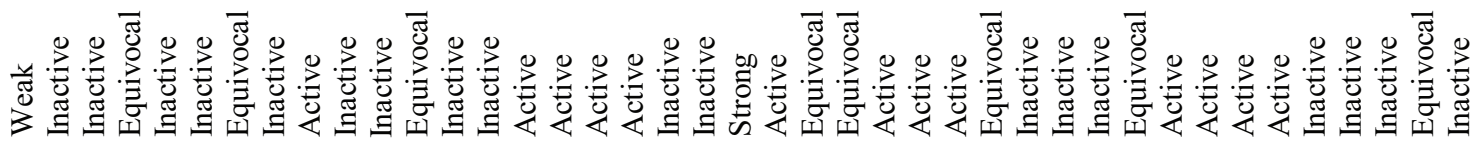

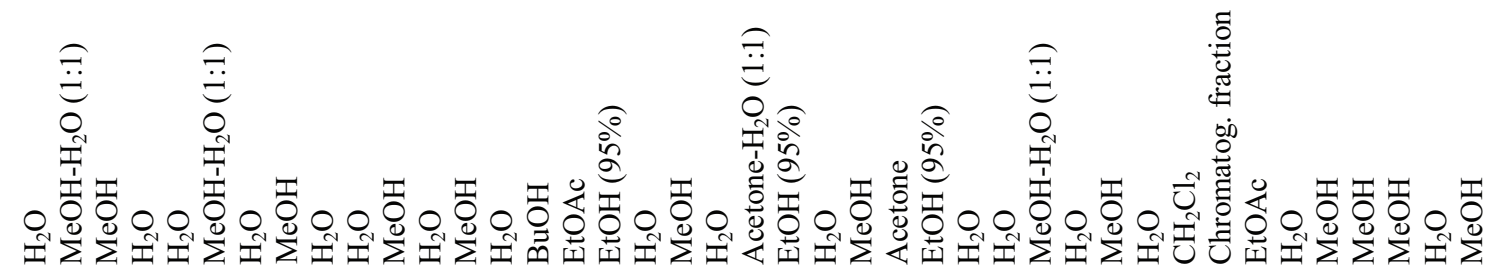

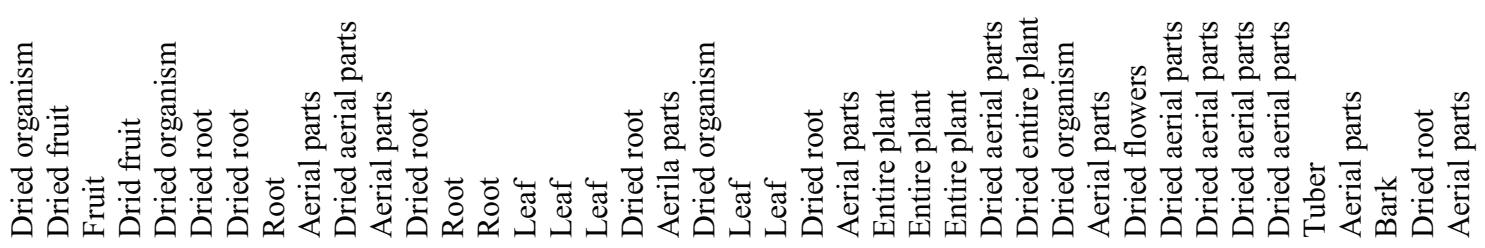

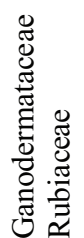
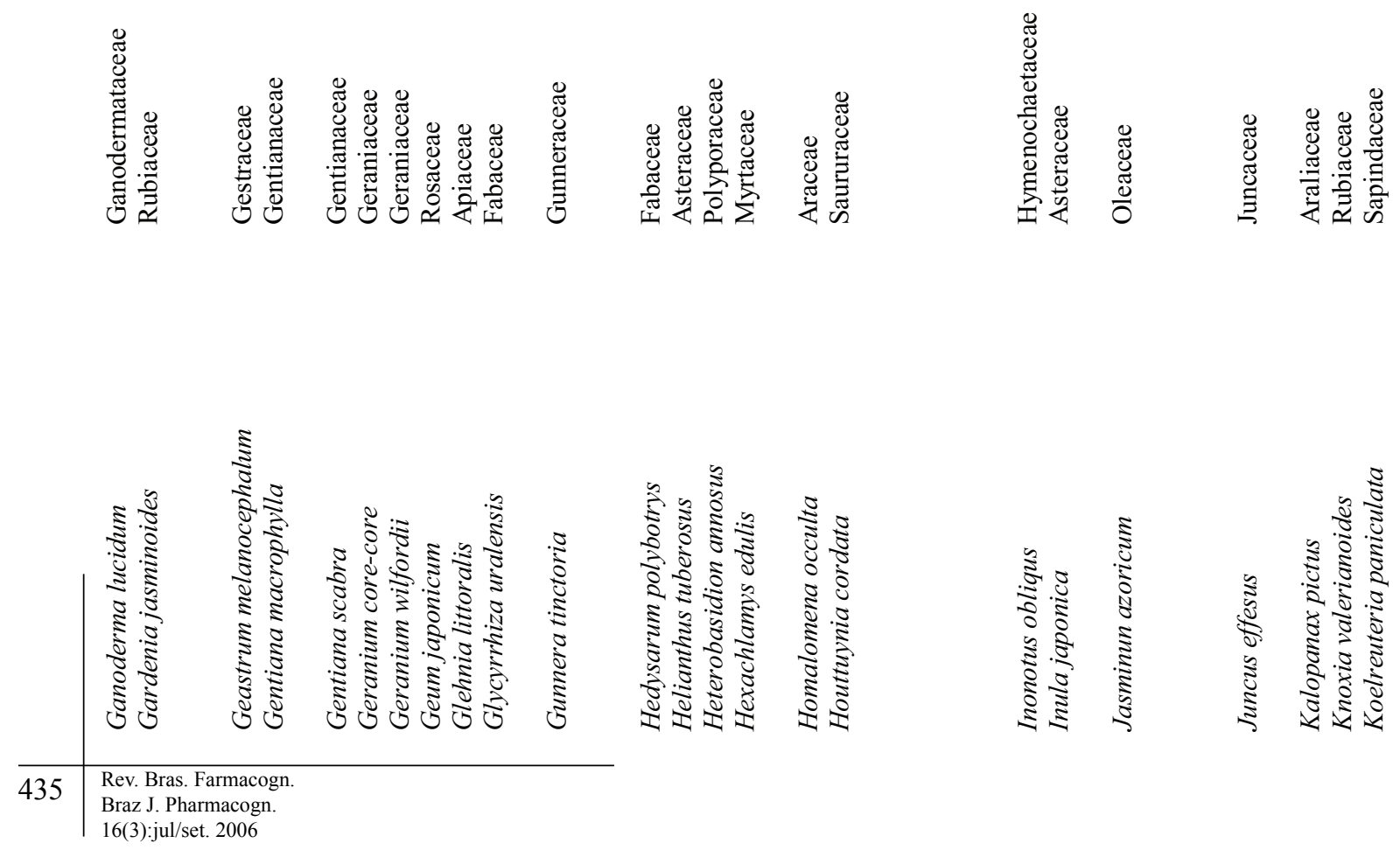


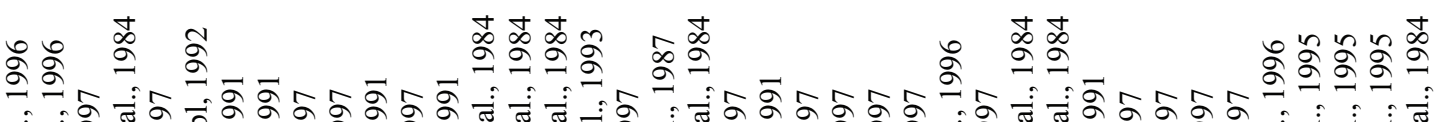

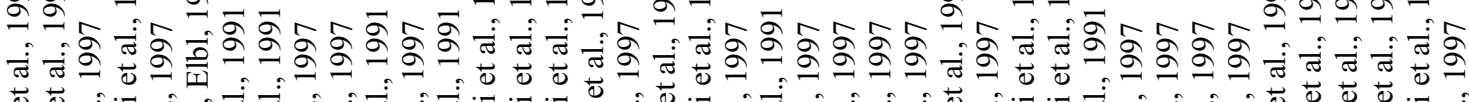

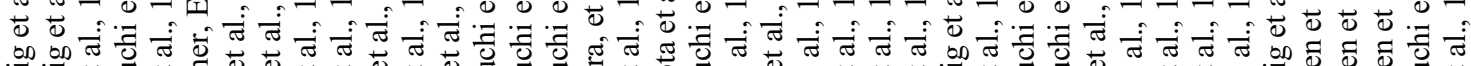

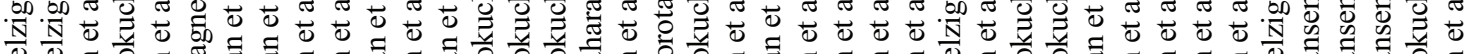

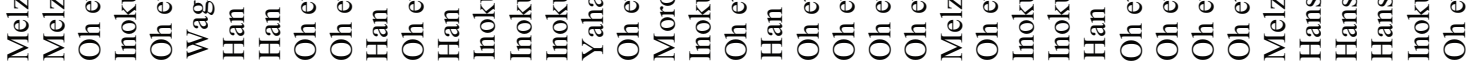

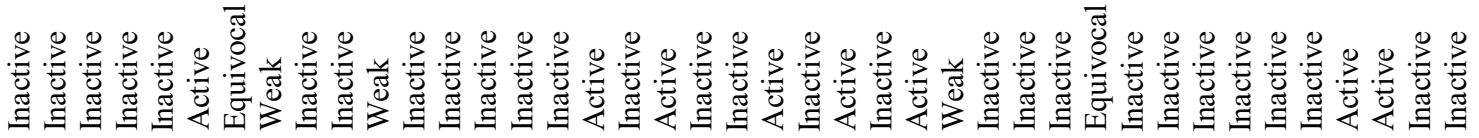

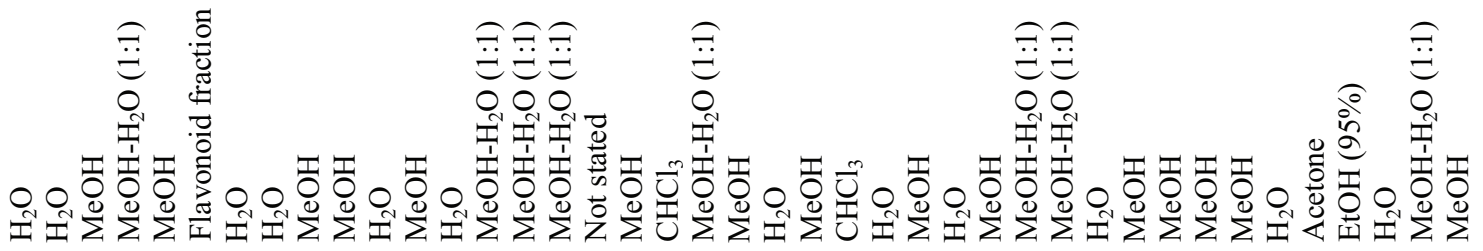

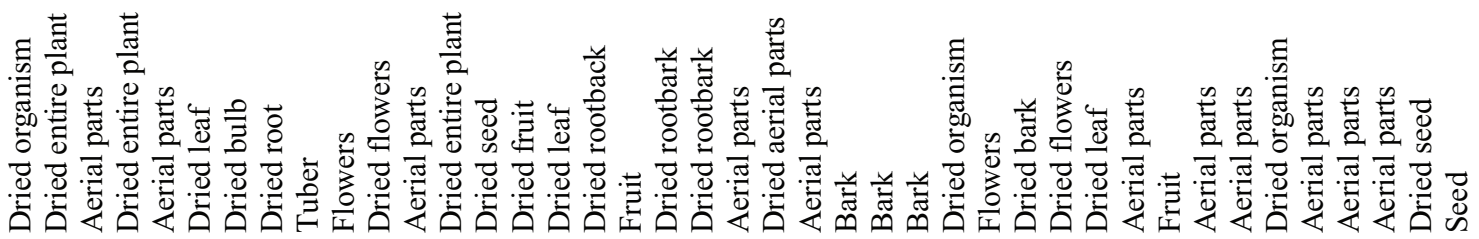
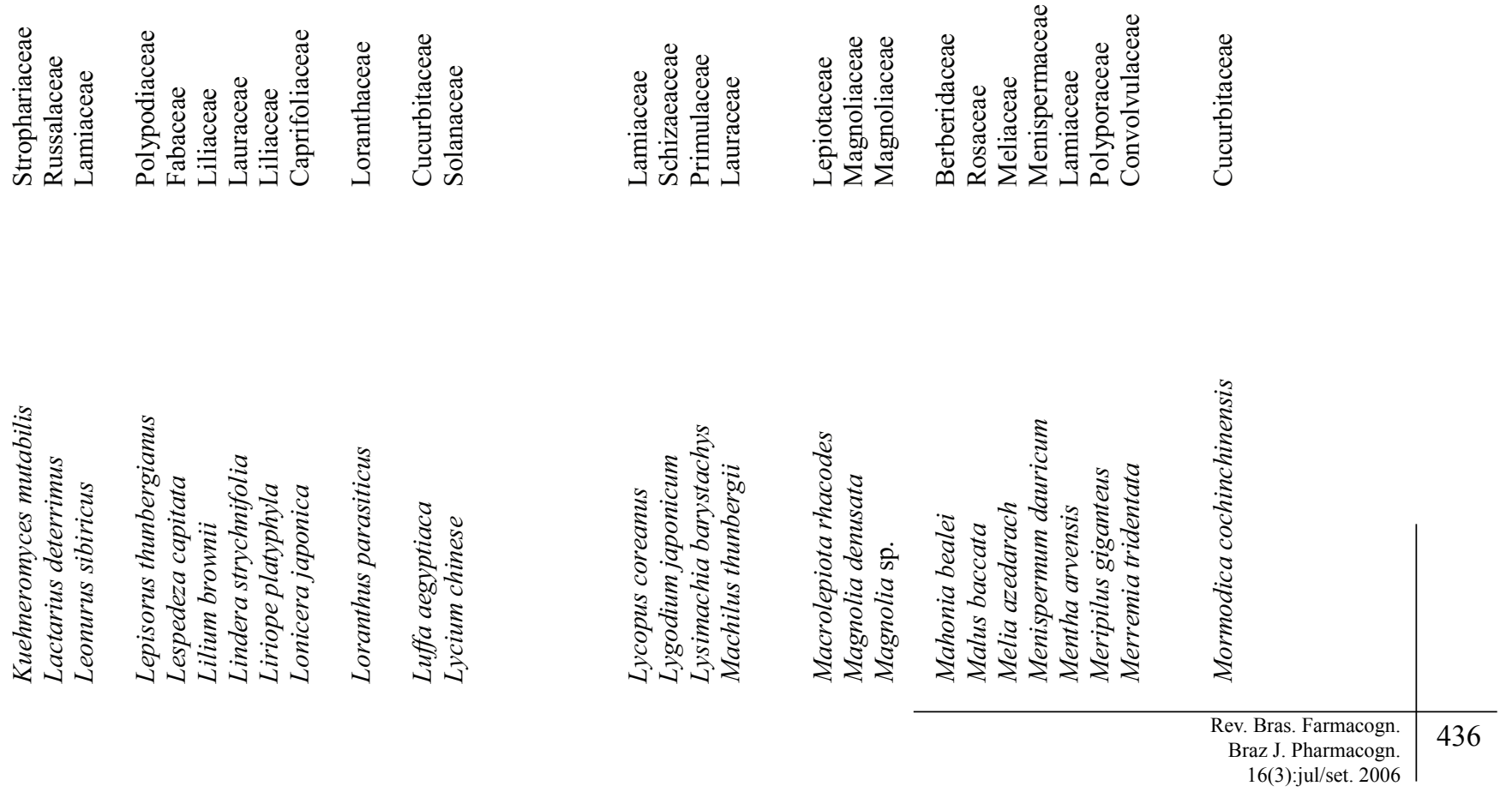


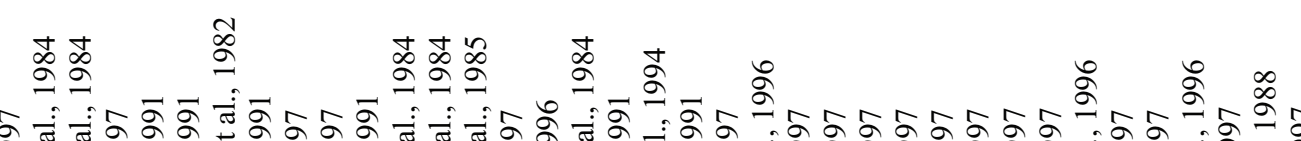

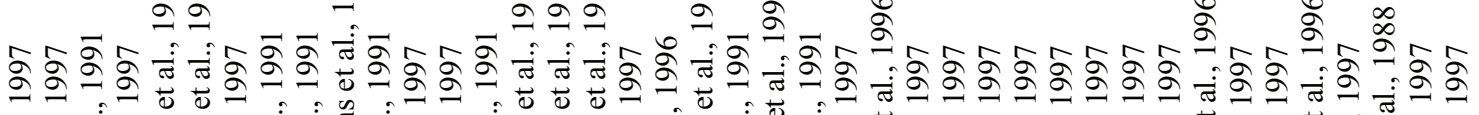

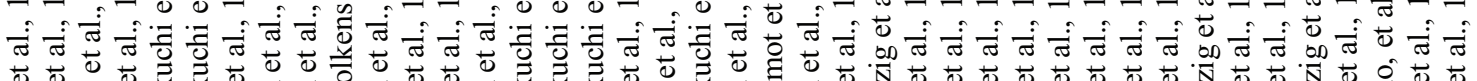

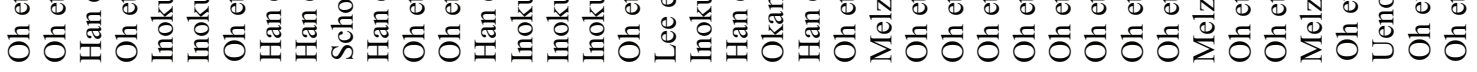

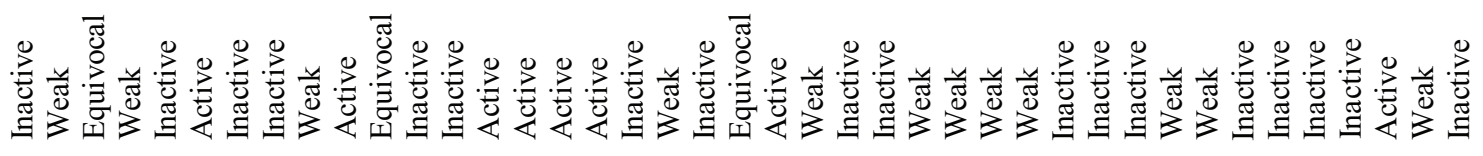

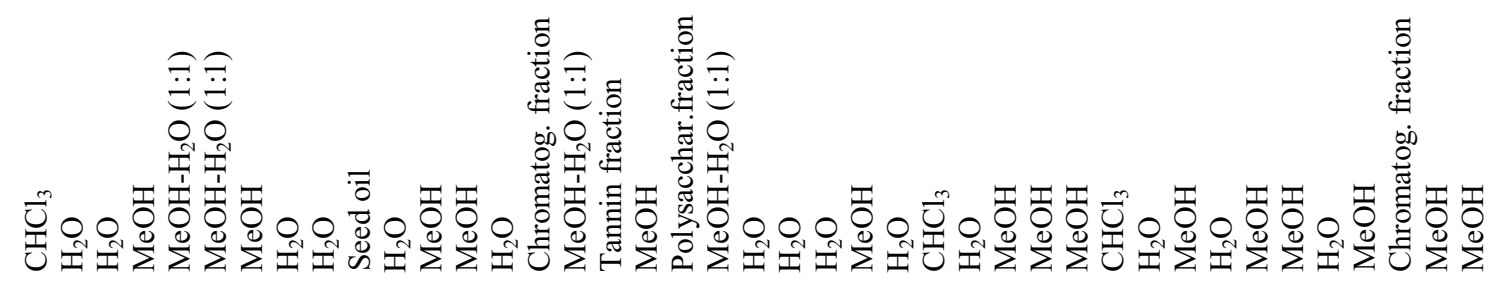

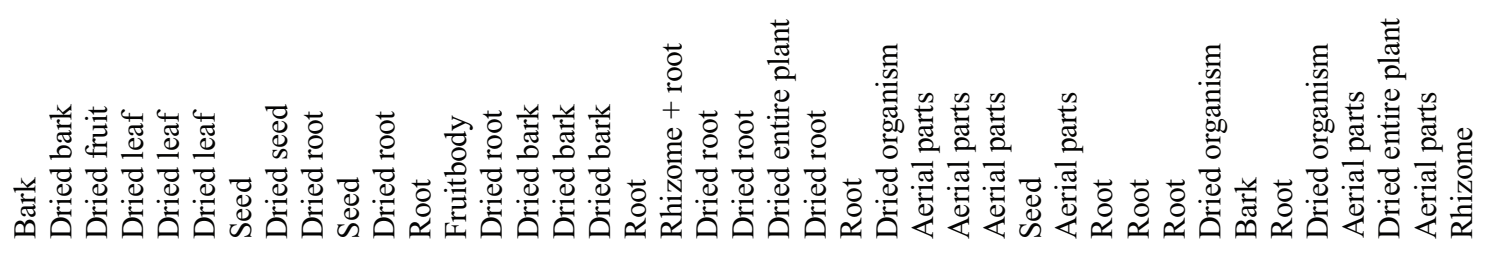
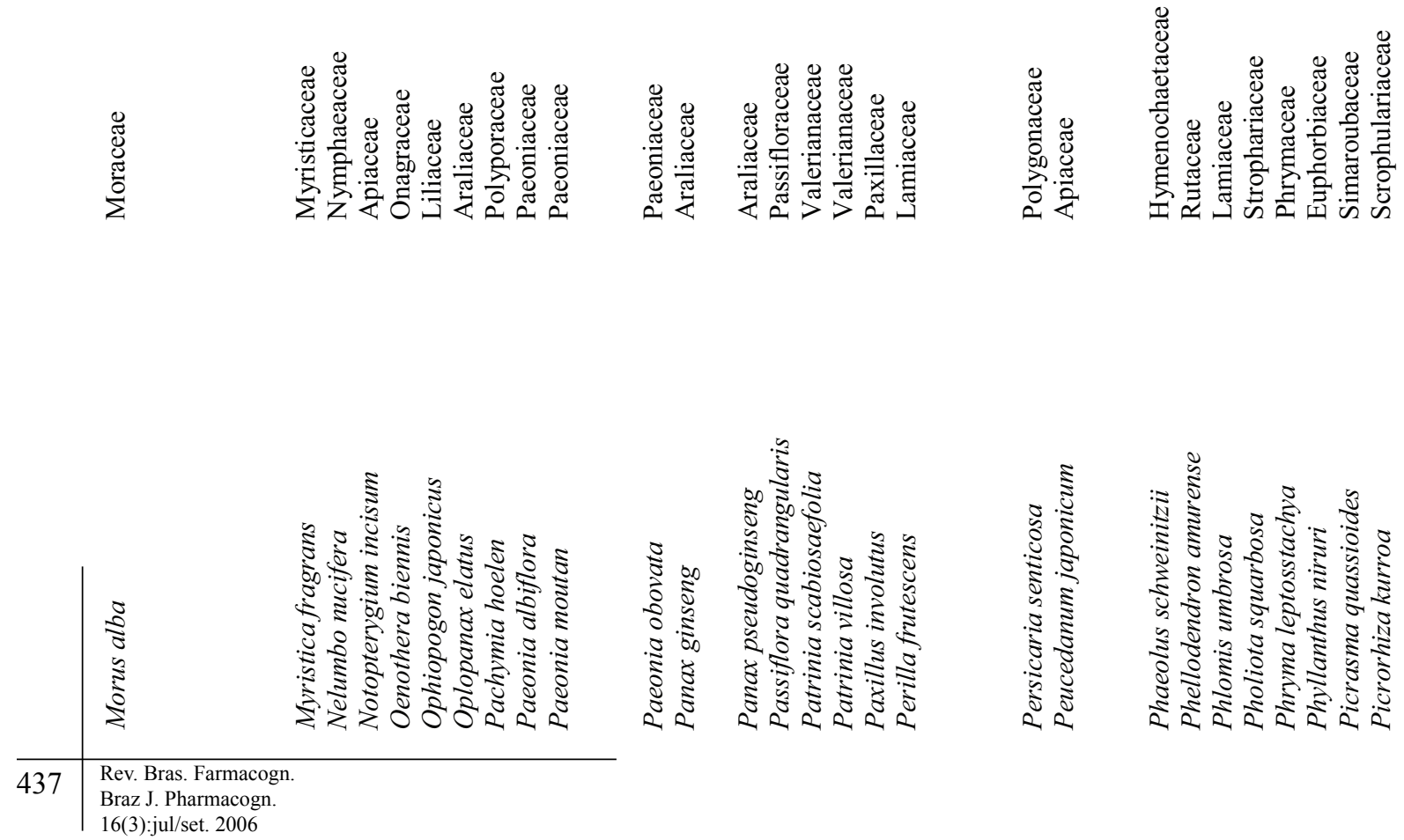


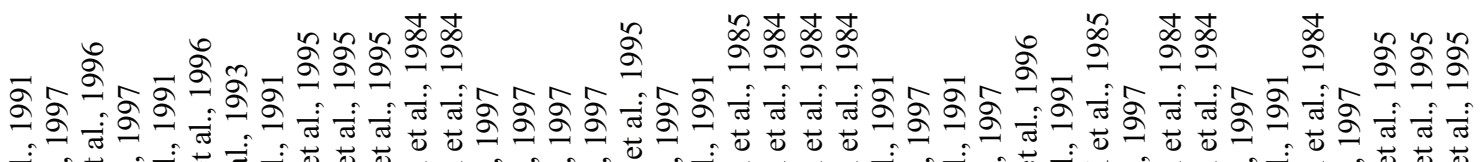

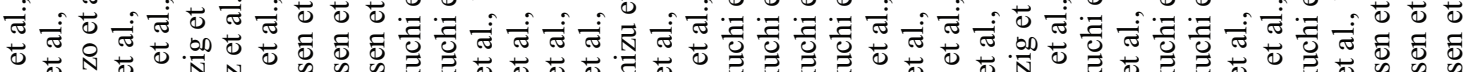

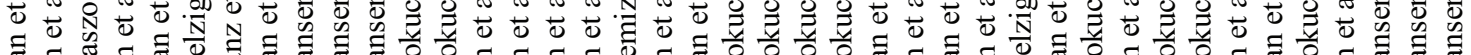

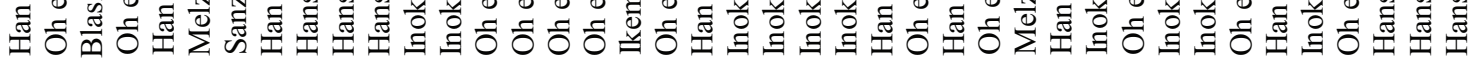

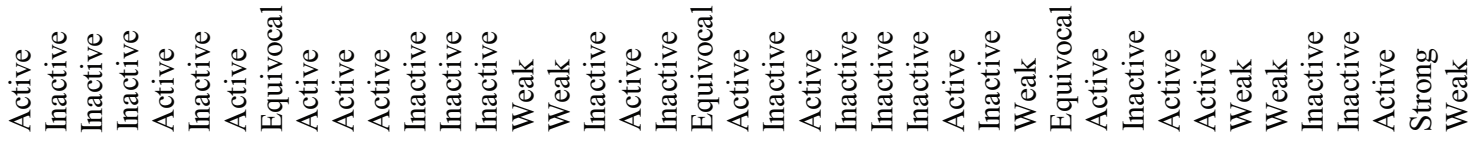

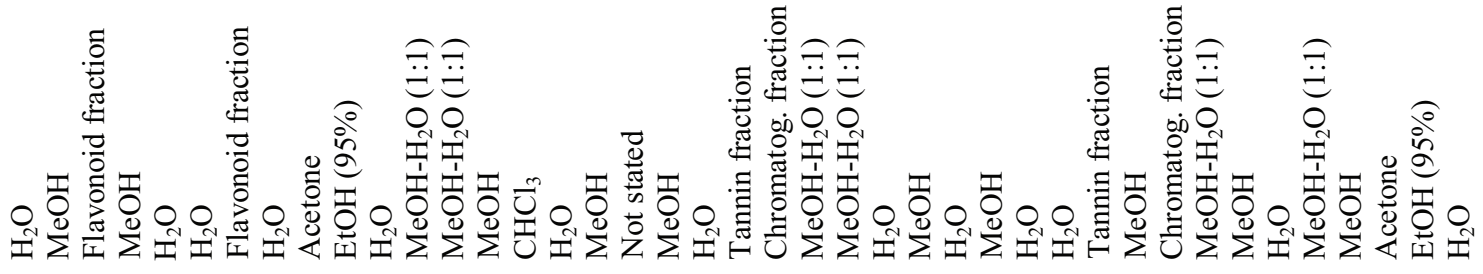

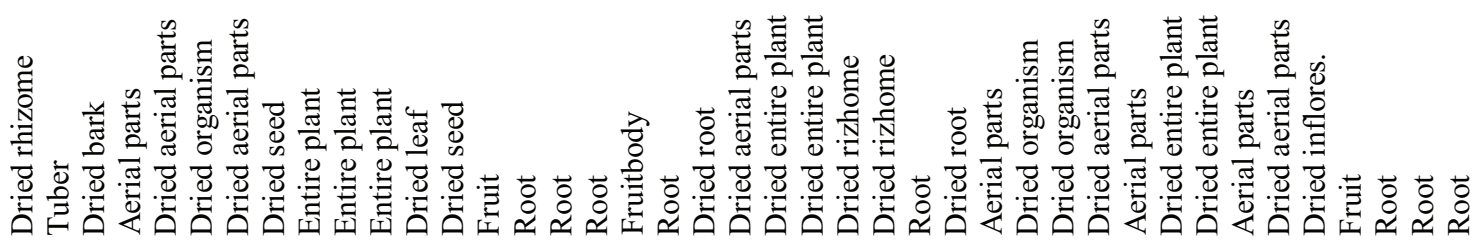
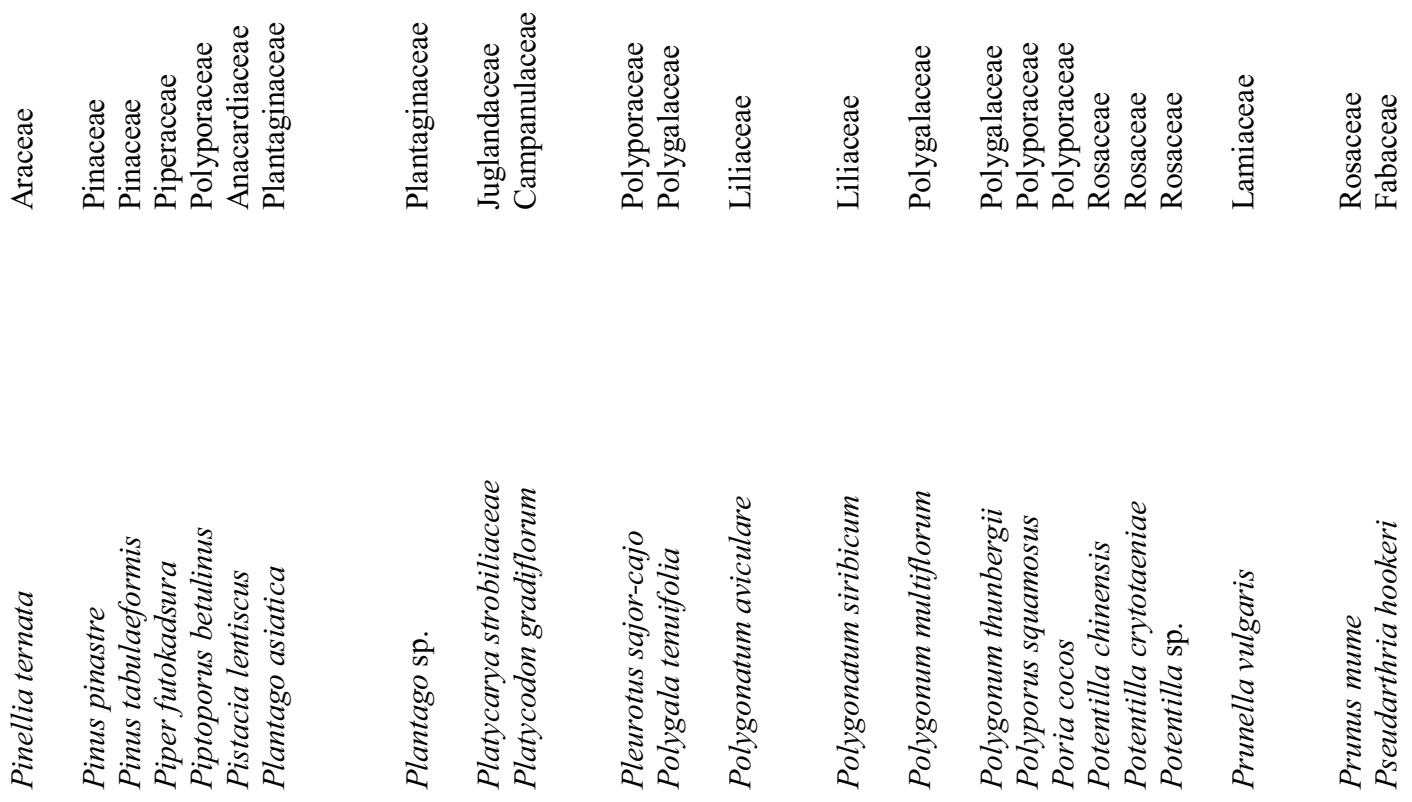


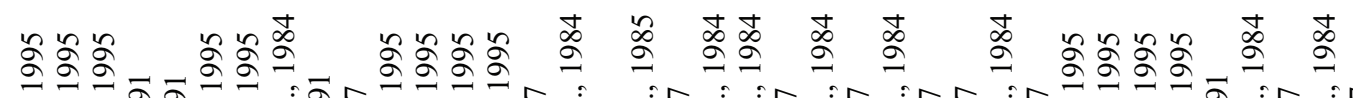

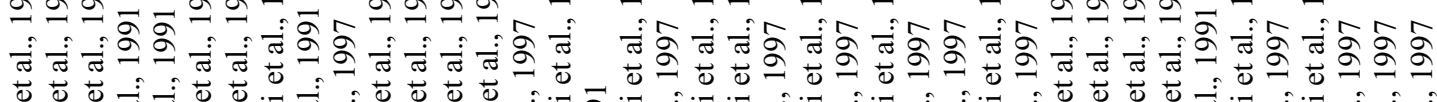

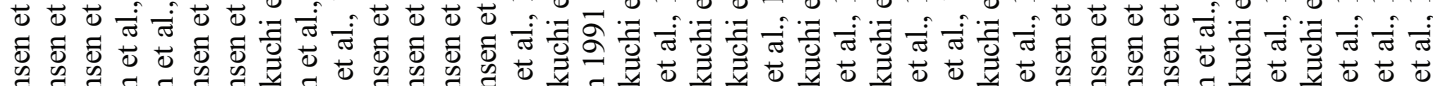

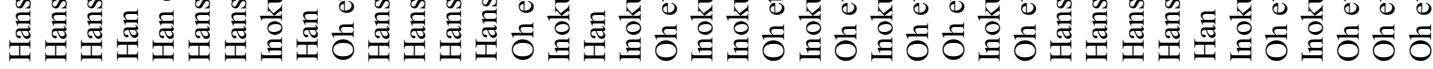

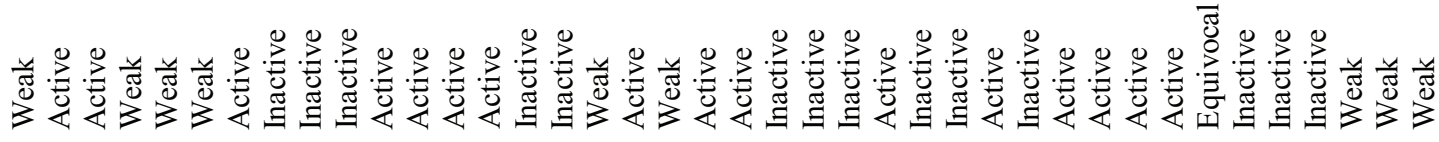

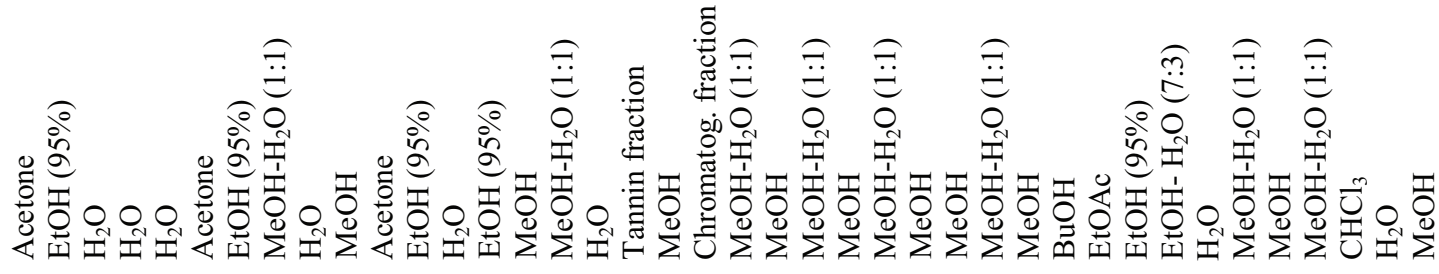

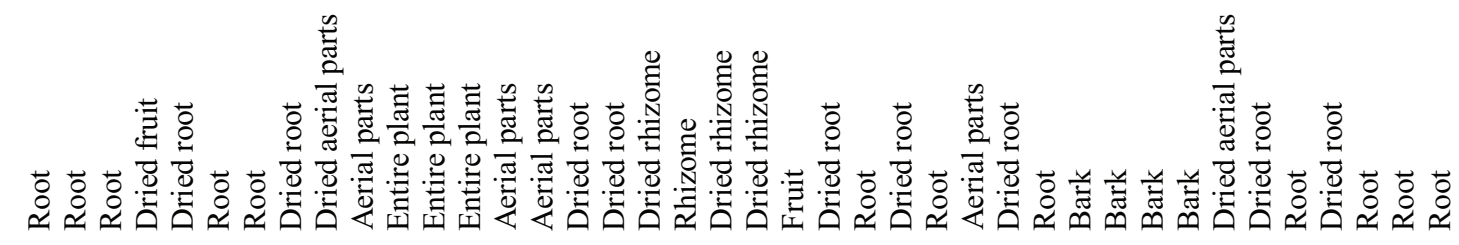

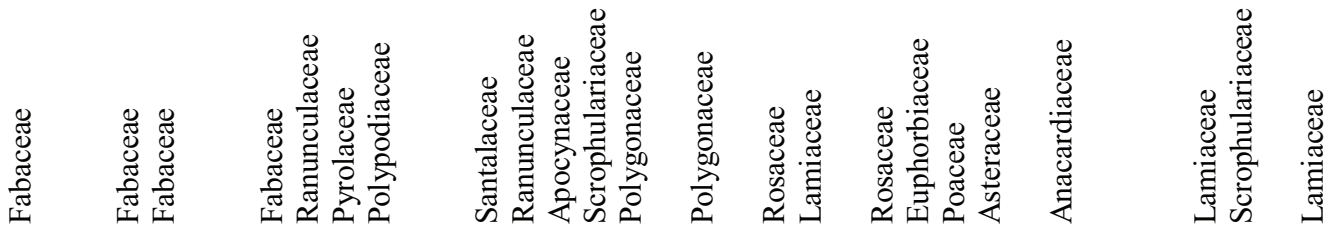

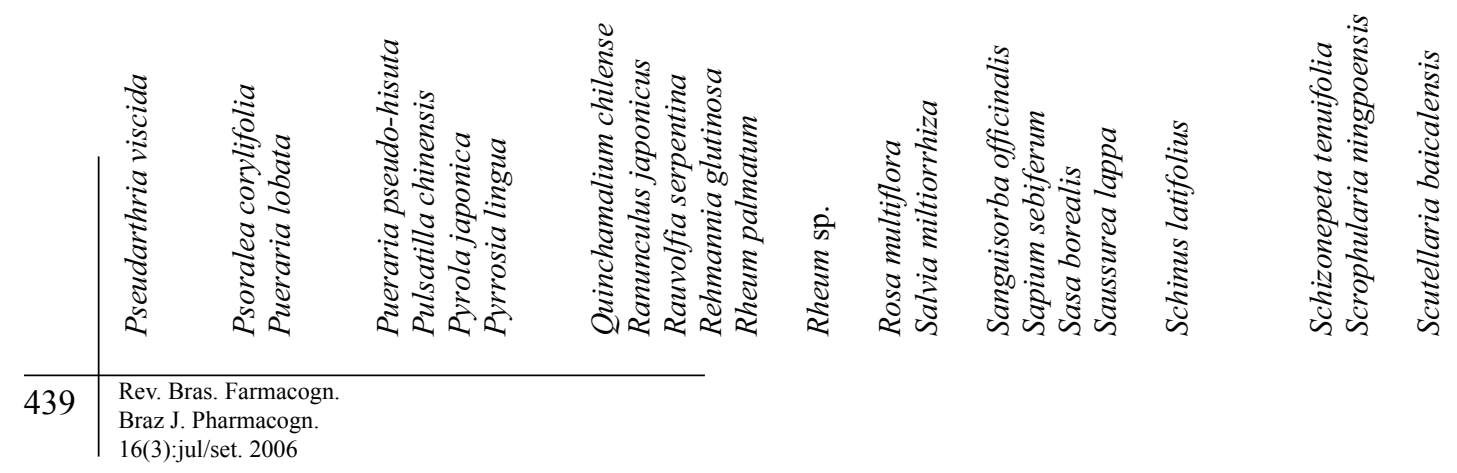




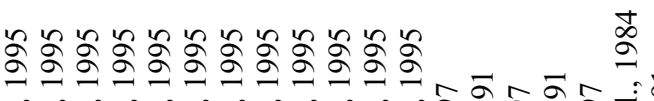

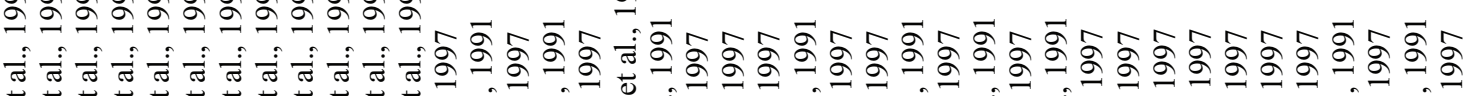

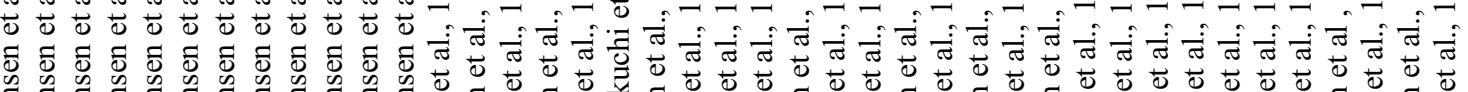

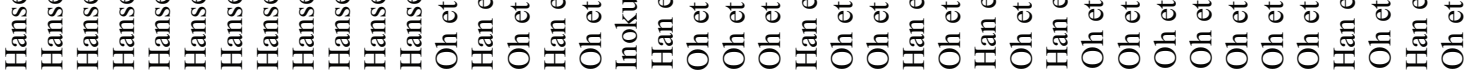

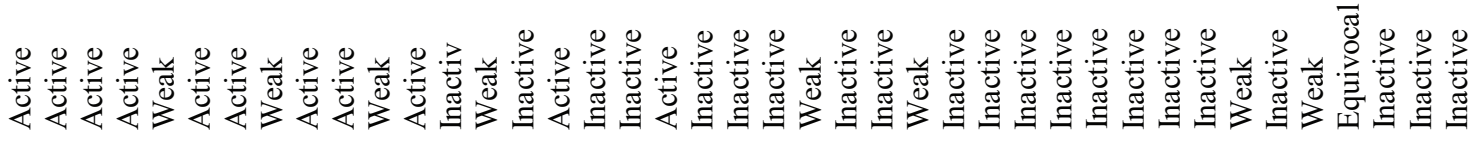

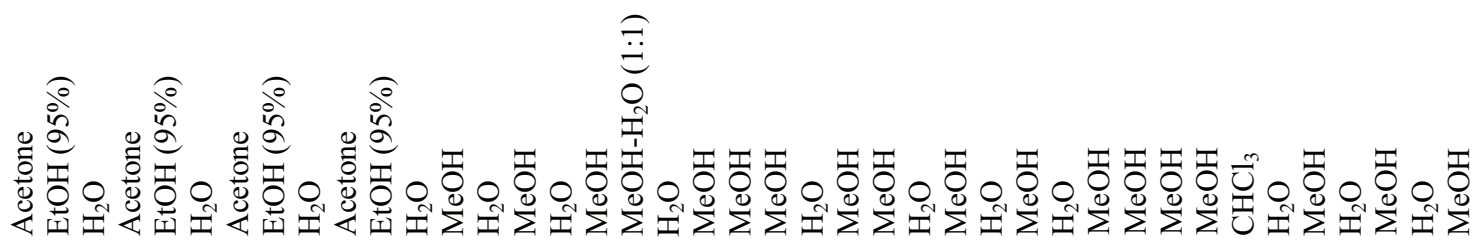

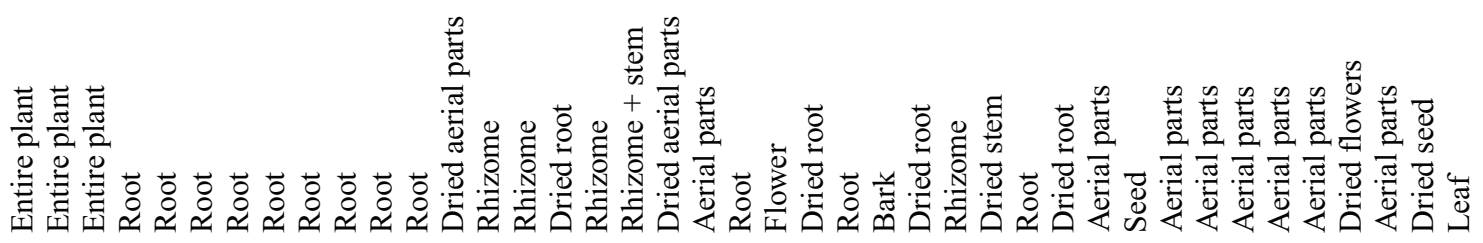

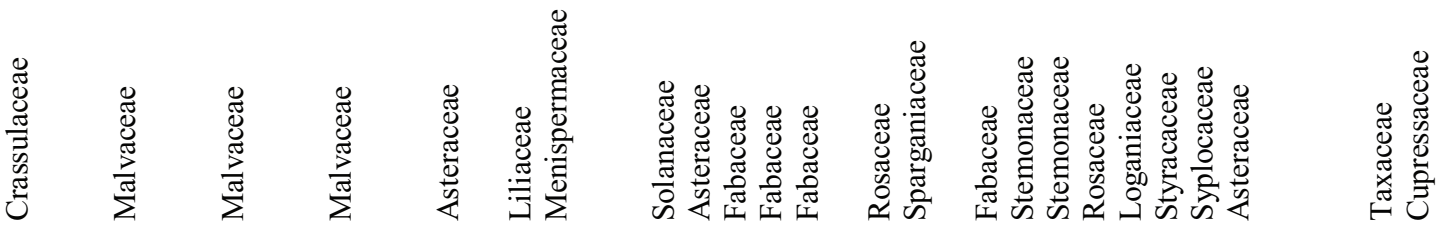

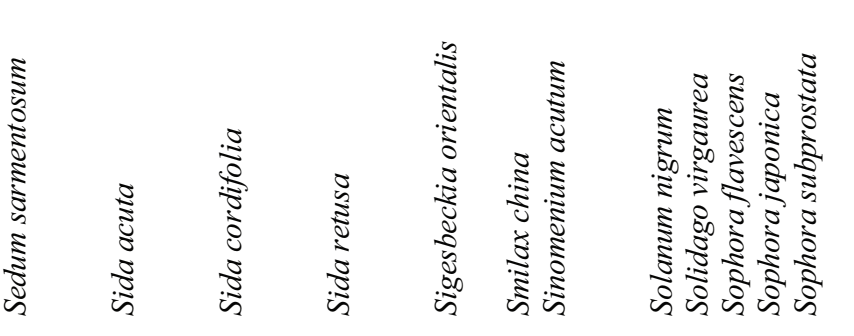
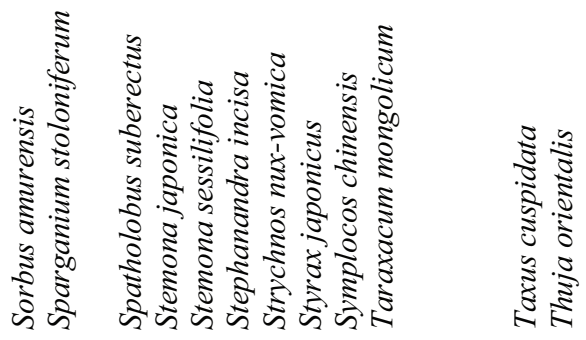


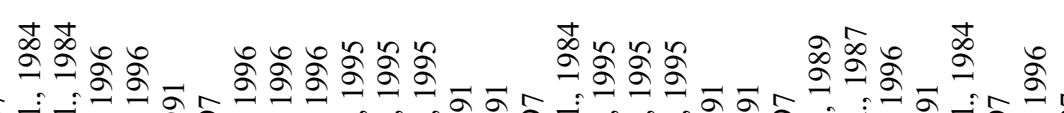

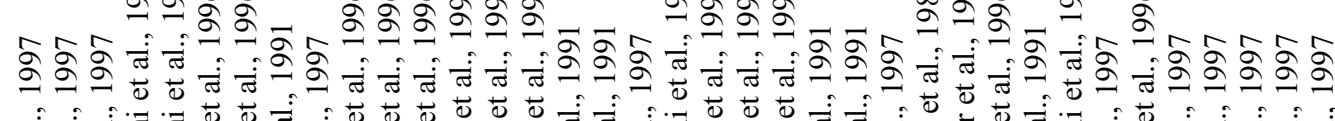

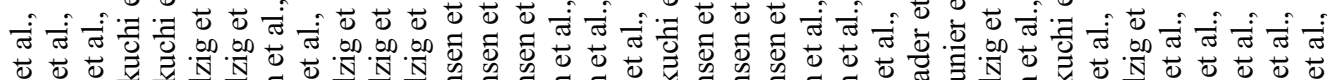

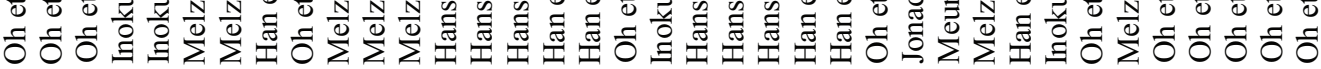

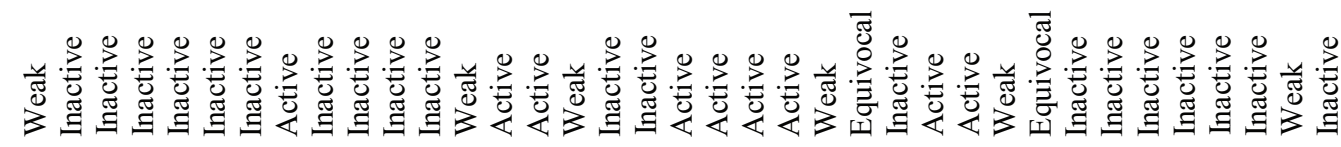

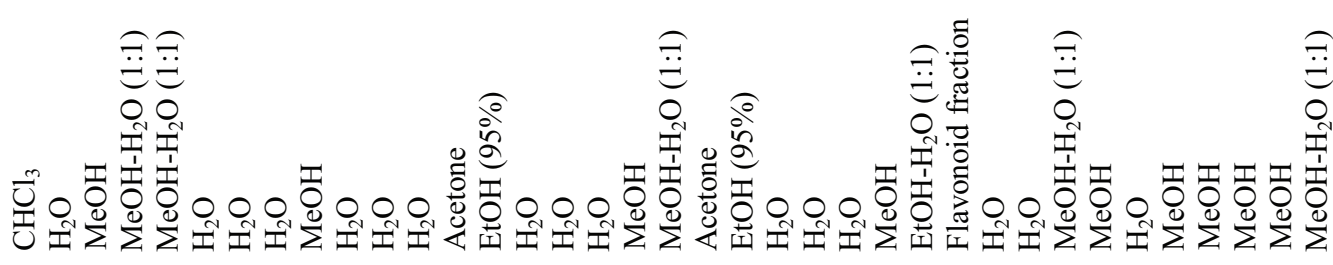
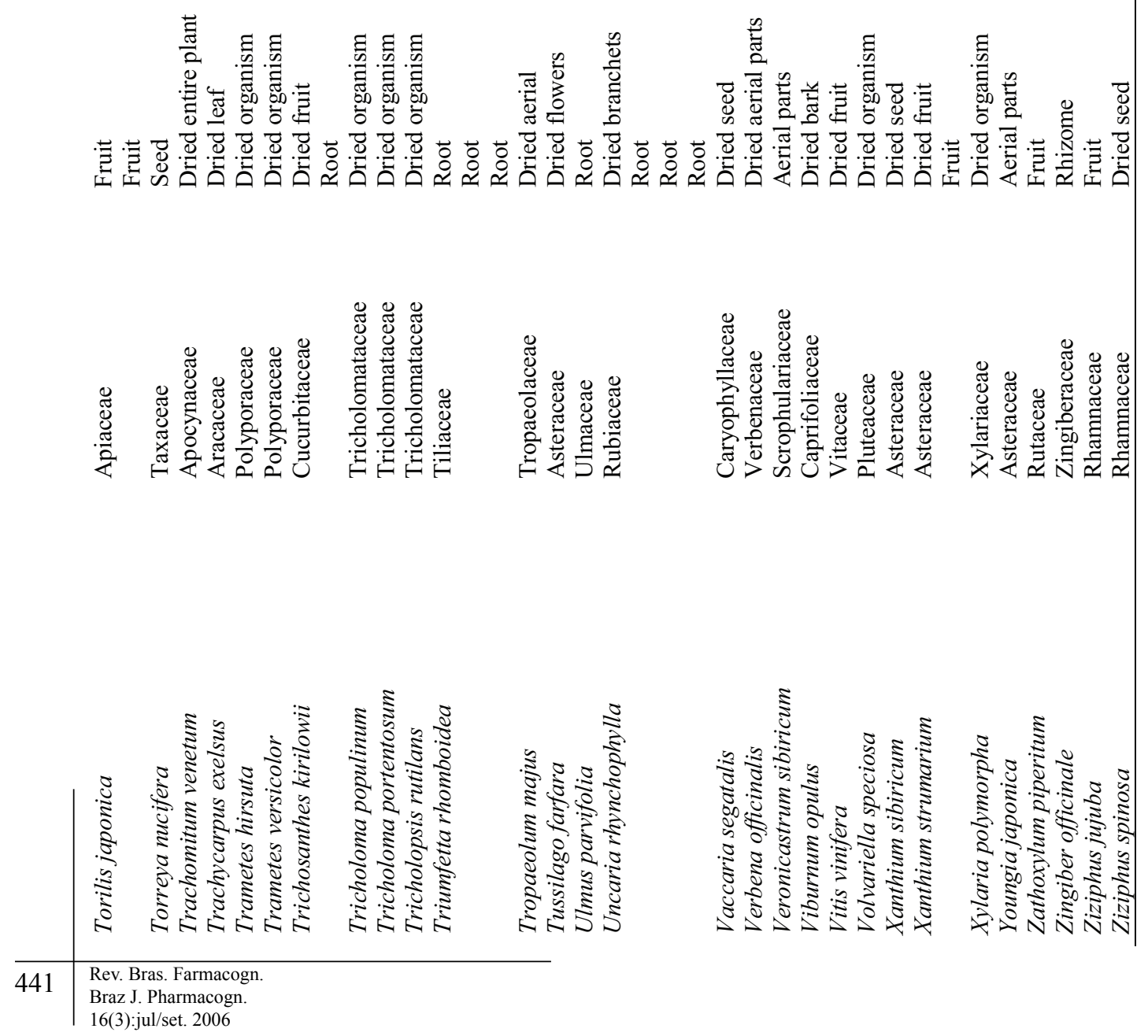


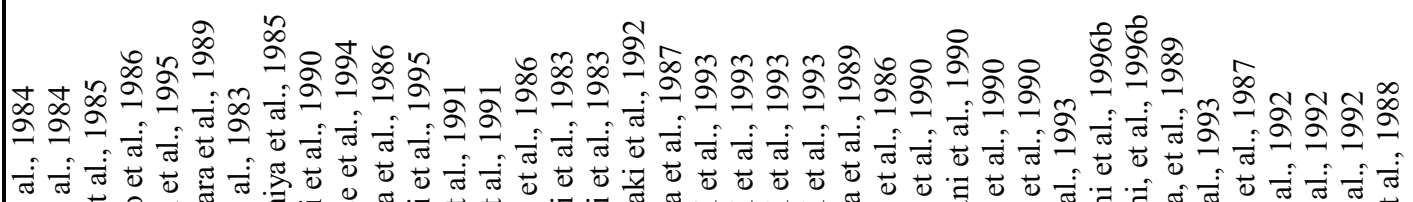

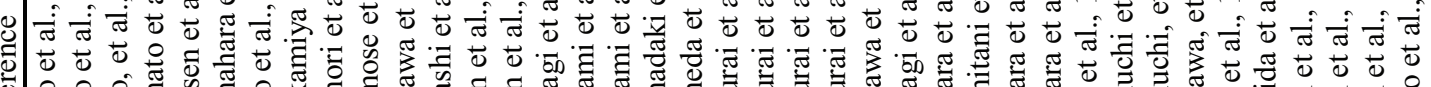

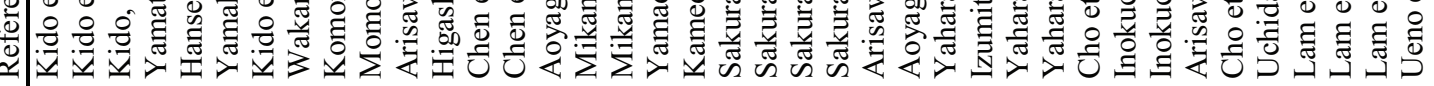

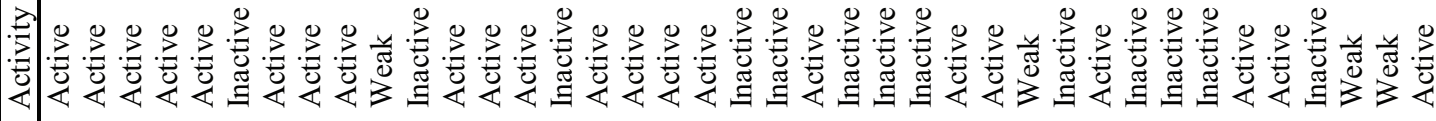

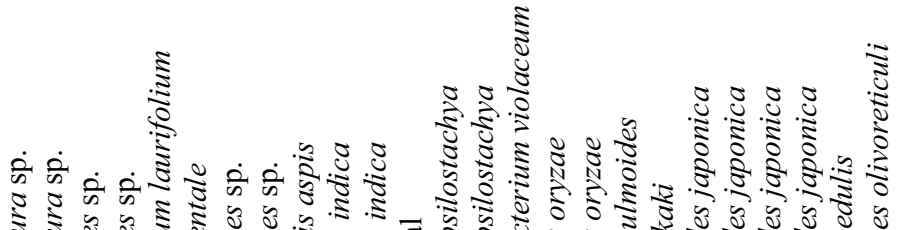

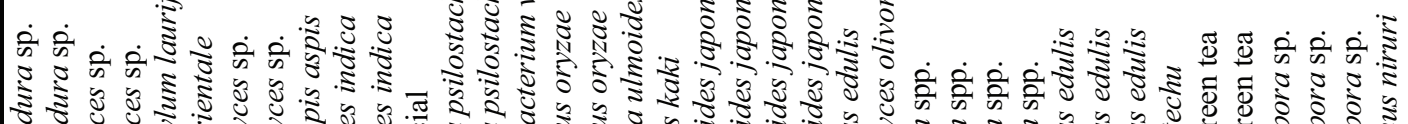

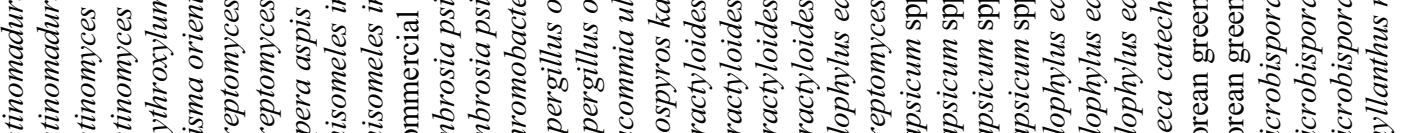

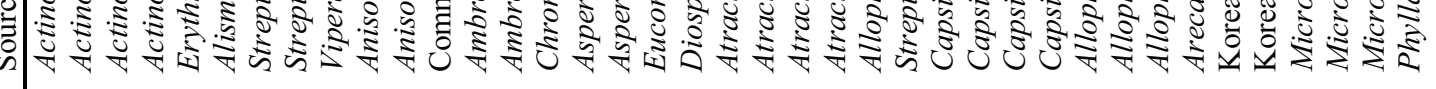

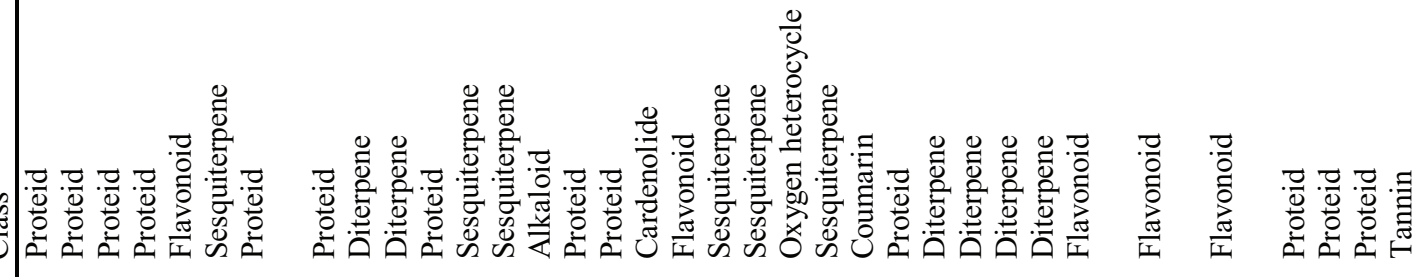




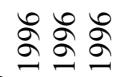

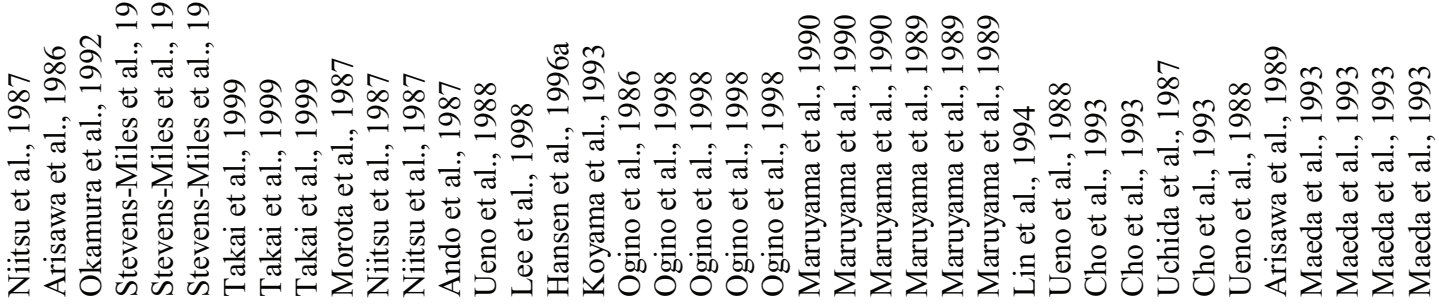

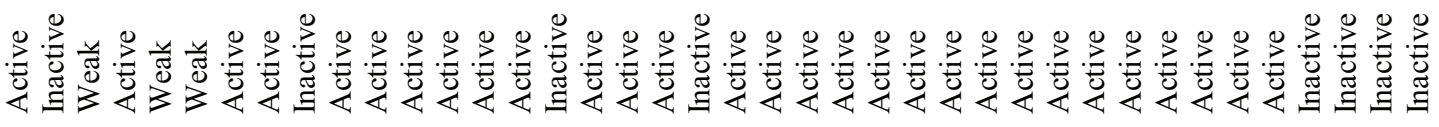

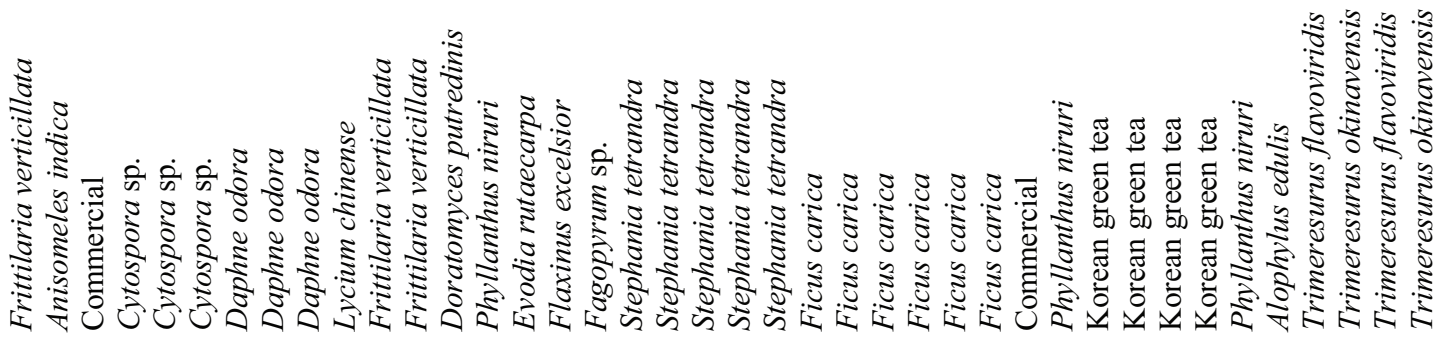

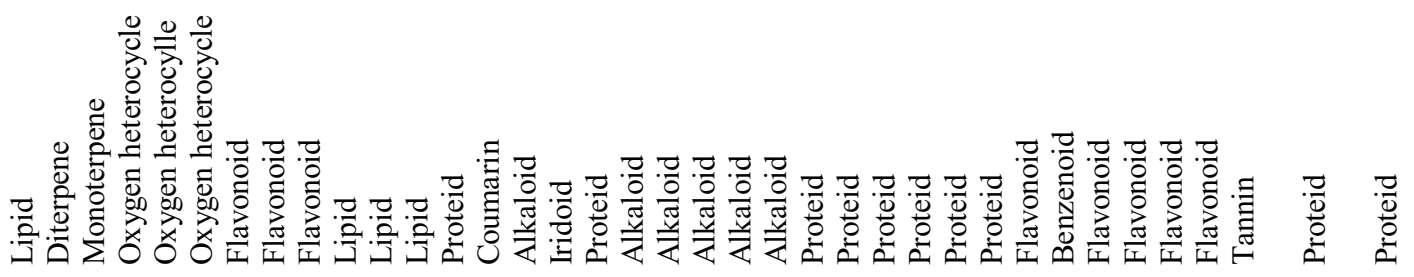

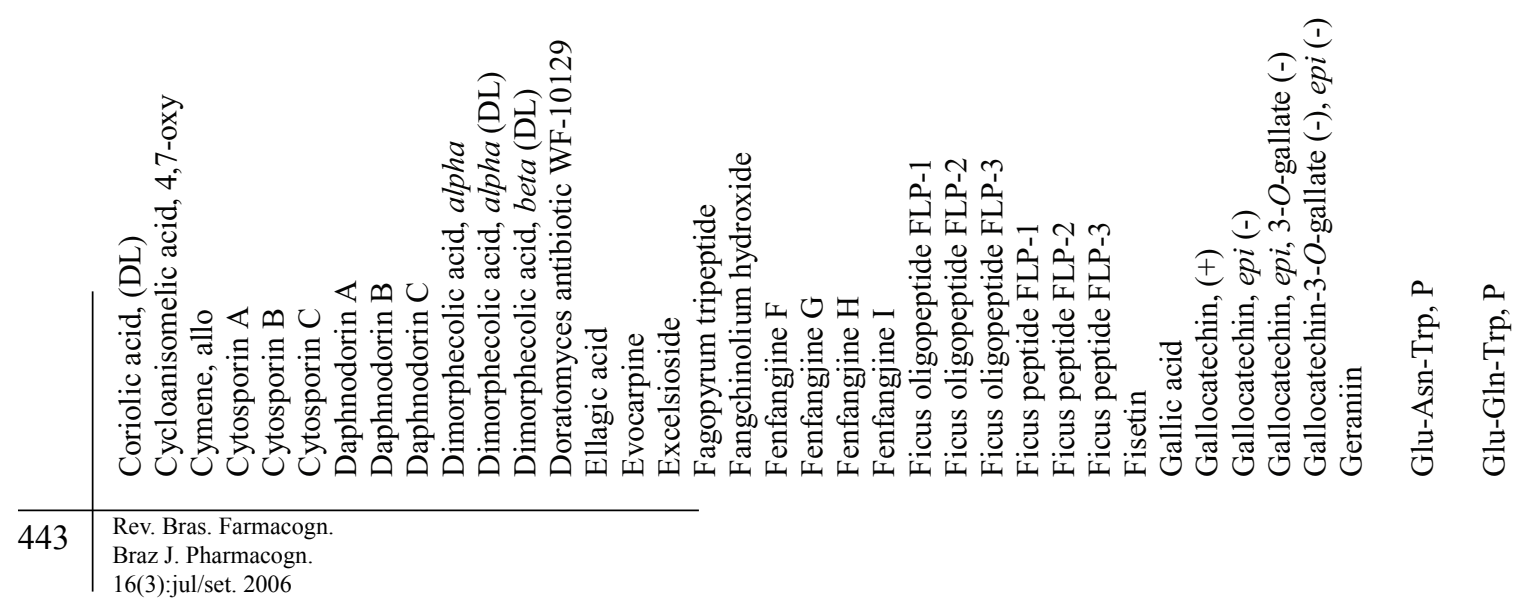




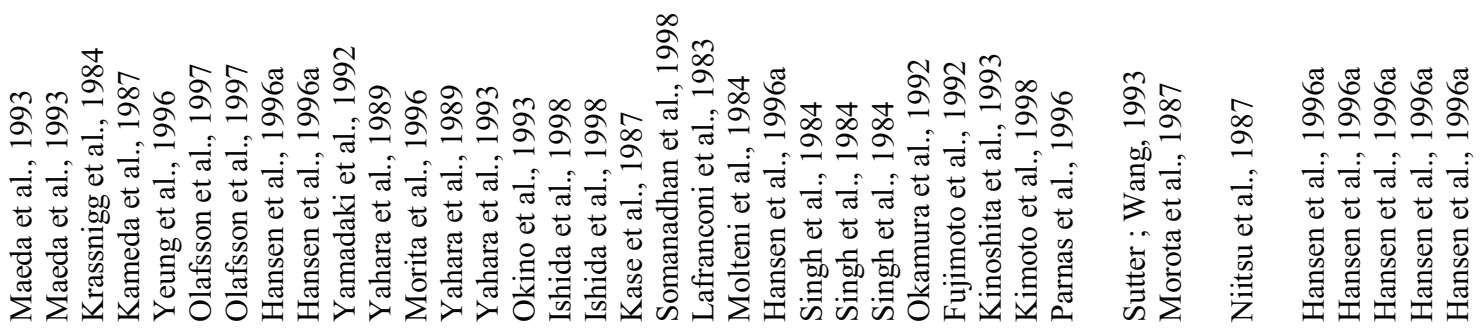

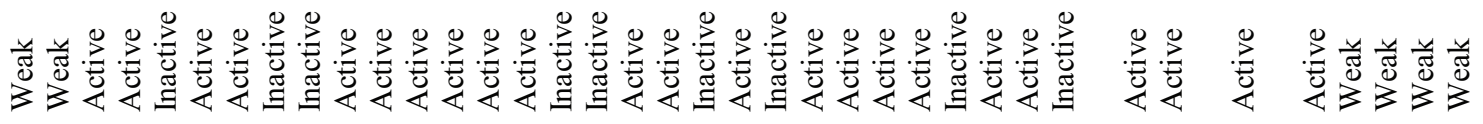

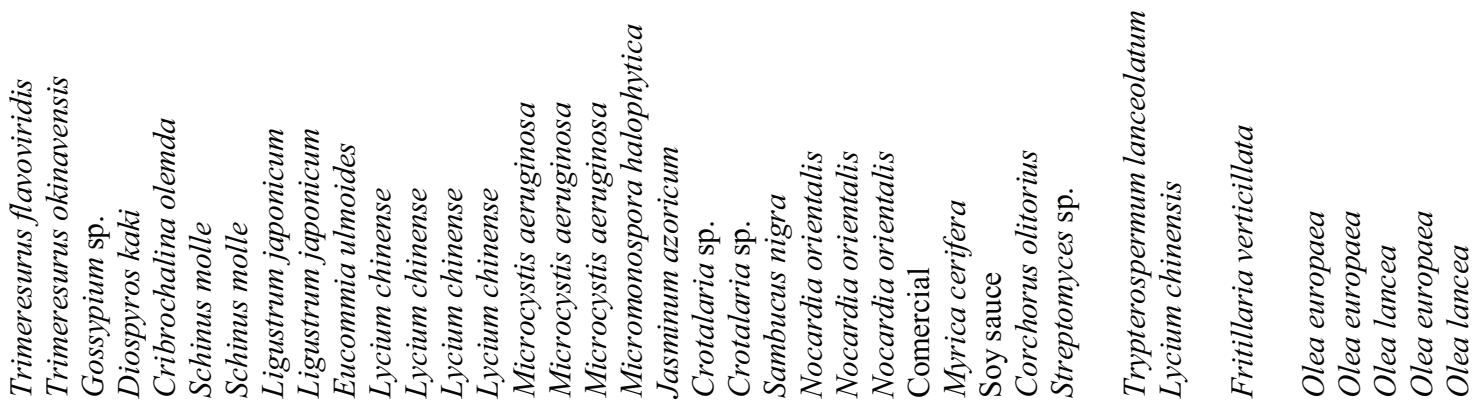

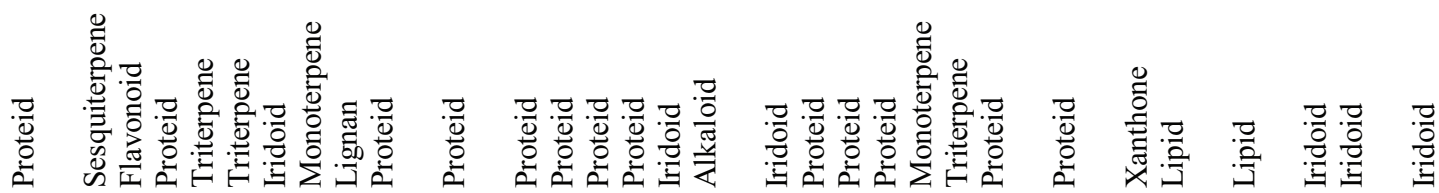
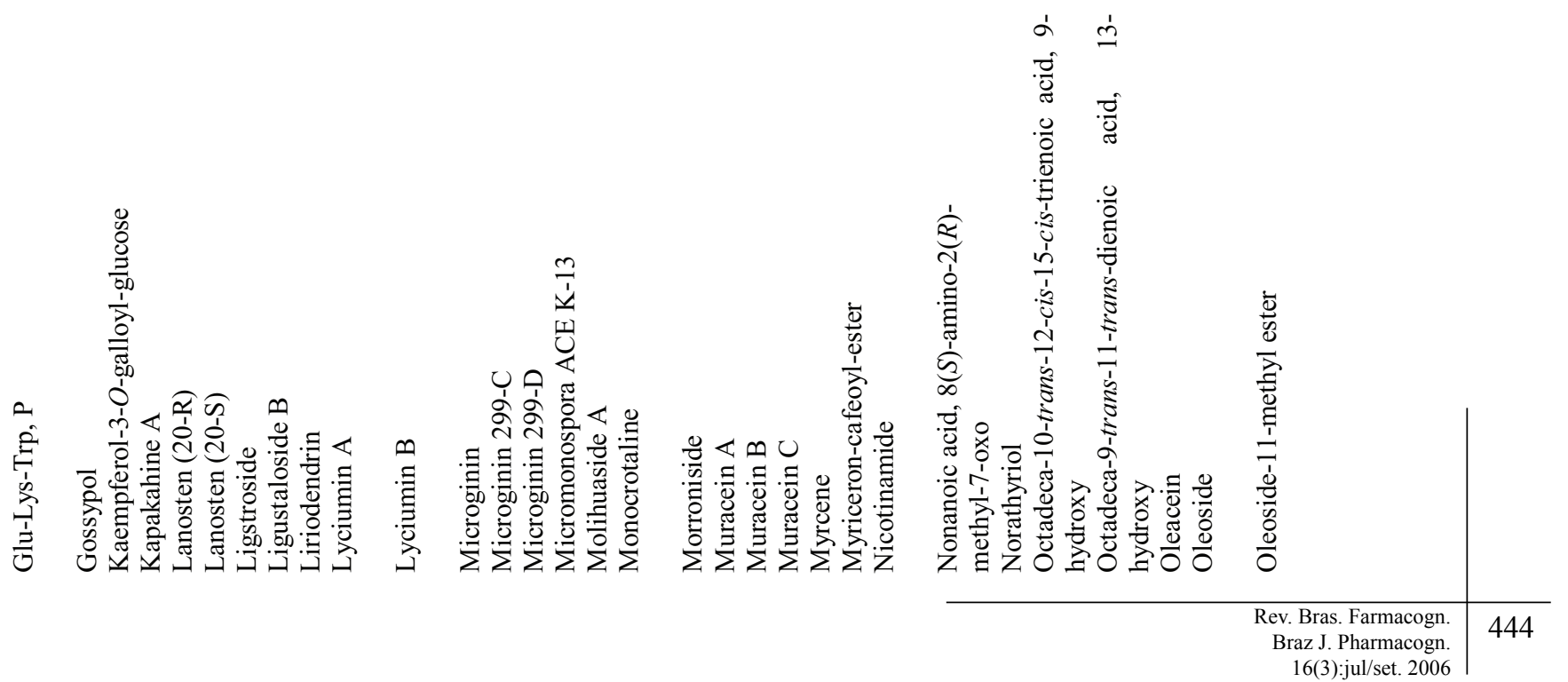


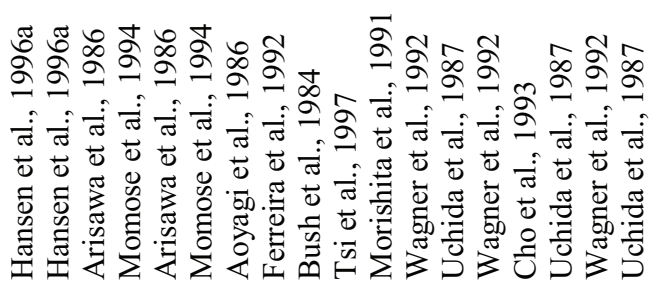

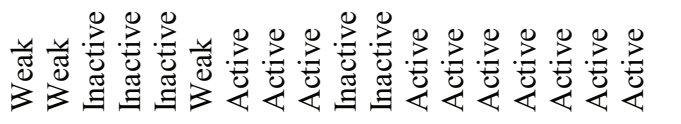

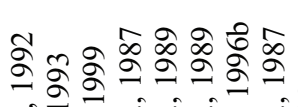

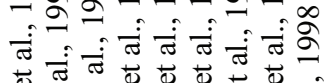

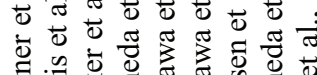

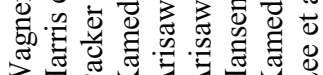

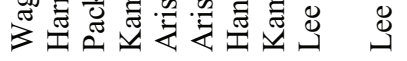

善器器

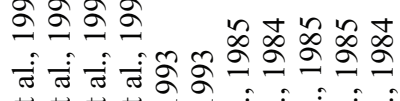

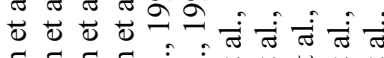

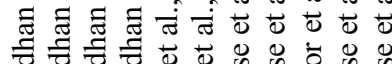

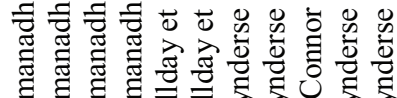

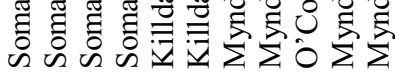
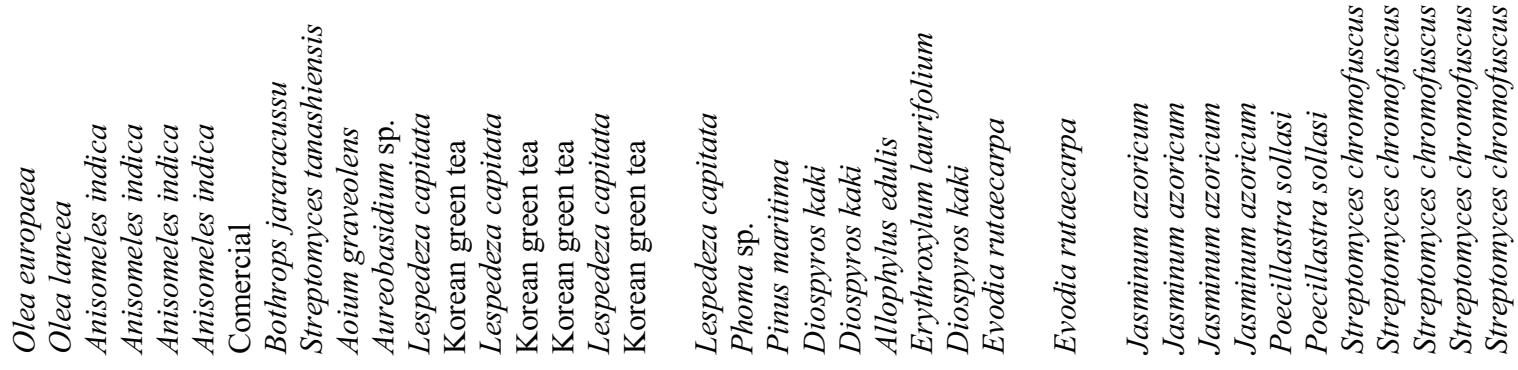

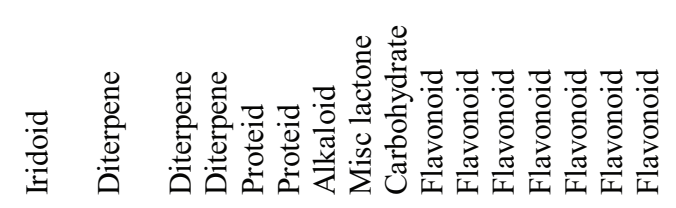
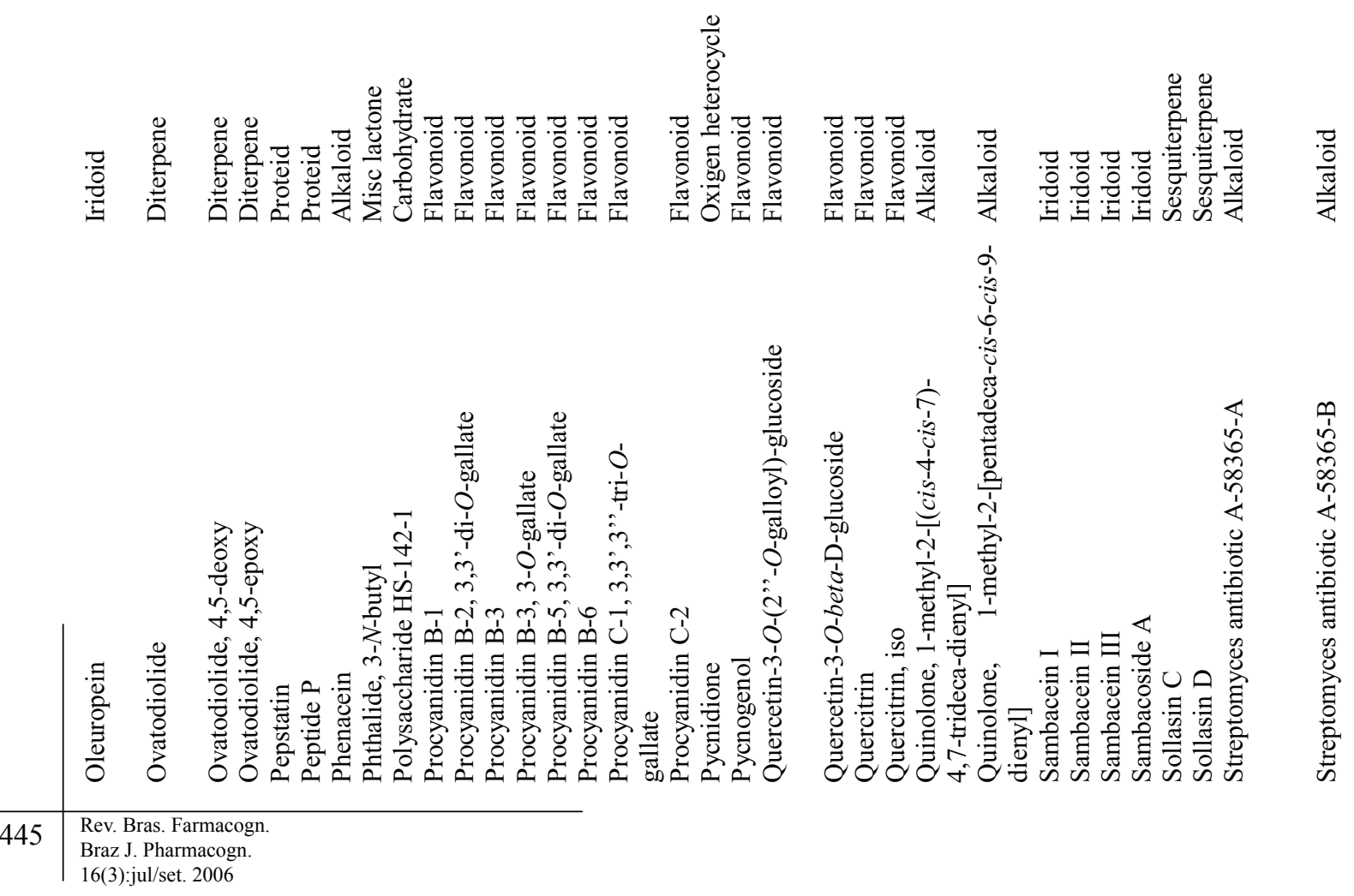


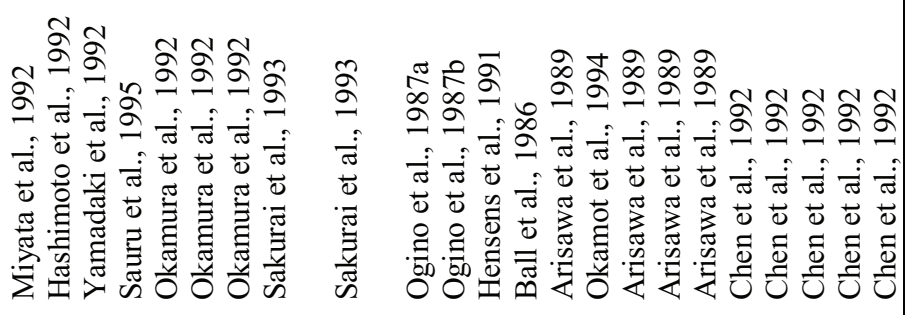

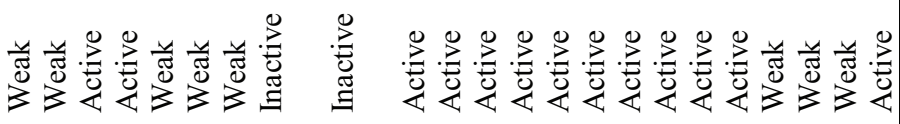
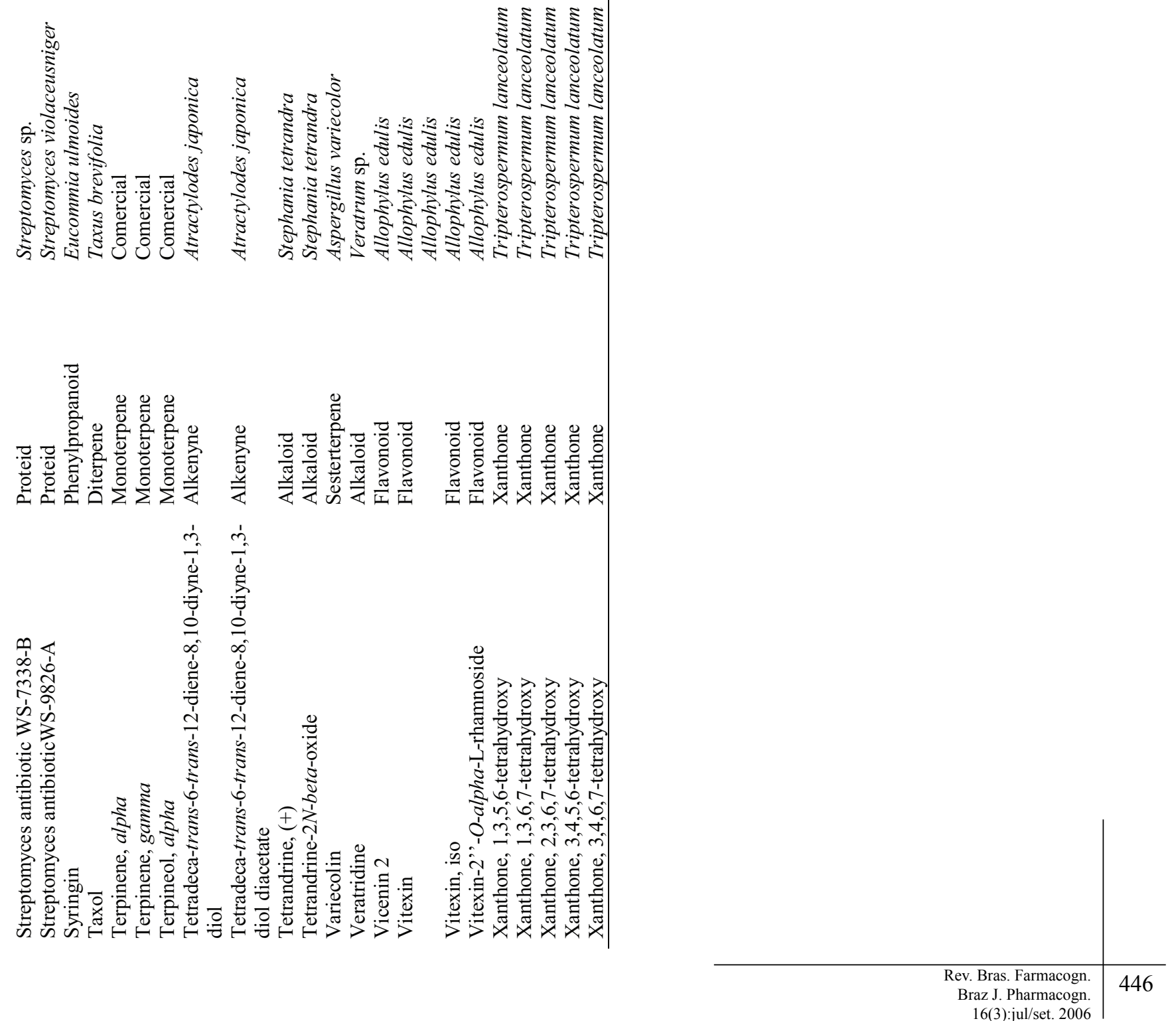